\title{
Neural Stem and Progenitor Cells Retain Their Potential for Proliferation and Differentiation into Functional Neurons Despite Lower Number in Aged Brain
}

\author{
Henrik Ahlenius, ${ }^{1,4}$ Violeta Visan, ${ }^{2,4}$ Merab Kokaia, ${ }^{3}$ Olle Lindvall, ${ }^{2,4}$ and Zaal Kokaia ${ }^{1,4}$ \\ ${ }^{1}$ Laboratory of Neural Stem Cell Biology, ${ }^{2}$ Laboratory of Neurogenesis and Cell Therapy, and ${ }^{3}$ Experimental Epilepsy Group, Section of Restorative \\ Neurology, Wallenberg Neuroscience Center, University Hospital, SE-221 84 Lund, Sweden, and ${ }^{4}$ Lund Stem Cell Center, SE-221 84 Lund, Sweden
}

\begin{abstract}
Neurogenesis in the subventricular zone (SVZ), which gives rise to new neurons in the olfactory bulb, continues throughout life but declines with increasing age. Little is known about how aging affects the intrinsic properties of the neural stem and progenitor cells (NSCs) in SVZ and the functional characteristics of their neuronal progeny. Here, we have compared the properties of NSCs isolated from embryonic lateral ganglionic eminence and adult and aged SVZ in mice using in vivo and in vitro systems, analyzed their gene expression profile, and studied their electrophysiological characteristics before and after differentiation into neurons. We show a loss of NSCs in SVZ from aged mice accompanied by reduced expression of genes for NSC markers, developmentally important transcription factors, and neurogenic factors. However, when isolated in vitro, the NSCs from SVZ of aged animals have capacity for proliferation and multilineage differentiation, including production of functional neurons, similar to that of NSCs in adult mice, albeit with lower efficacy. These properties are of major importance when considering therapeutic applications of neuronal replacement from endogenous NSCs in the injured, aged brain.
\end{abstract}

\section{Introduction}

Neural stem and progenitor cells (NSCs) in the lateral ganglionic eminence (LGE) and adult and aged subventricular zone (SVZ) ensure neurogenesis during embryonic development and throughout adult life. However, NSC proliferation and neuroblast formation in SVZ are decreased in old animals (Tropepe et al., 1997; Enwere et al., 2004). Aged mice show deficits in olfactory discrimination, most likely attributable to reduced neurogenesis (Enwere et al., 2004). The age-dependent decline of neurogenesis has been attributed to decreased proliferation and growth factor signaling (Tropepe et al., 1997; Enwere et al., 2004; Shetty et al., 2005), increased levels of corticosteroids (Cameron and McKay, 1999; Montaron et al., 1999, 2006), and senescence of neural progenitors (Molofsky et al., 2006). Whether there is a loss of NSCs in aged brain is not clear. Reports are conflicting regarding NSCs in the dentate gyrus (Shetty et al., 2005; Olariu et al., 2007; Hattiangady and Shetty, 2008). In SVZ, the number of NSCs was described to be unaltered in old animals (Tropepe et al., 1997), but studies of proliferation, neurosphere formation,

\footnotetext{
Received Dec. 17, 2008; revised Feb. 5, 2009; accepted March 2, 2009.

This work was supported by grants from Swedish Research Council, Swedish Diabetes Foundation, Juvenile Diabetes Research Foundation, European Union project LSHB-CT-2006-037526 (STEMSTROKE), and the King Gustav V and Queen Victoria Foundation. We thank M. Lundahl and U. Sparrhult-Björk for technical assistance, and S. Aradottir and A. Fossum for help with cell sorting.

Correspondence should be addressed to Dr. Zaal Kokaia, Laboratory of Neural Stem Cell Biology, Section of Restorative Neurology, Stem Cell Center, University Hospital, SE-221 84 Lund, Sweden. E-mail: Zaal.Kokaia@med.lu.se.

DOI:10.1523/JNEUROSCI.6003-08.2009

Copyright $\odot 2009$ Society for Neuroscience $\quad$ 0270-6474/09/294408-12\$15.00/0
}

and ultrastructure (Enwere et al., 2004; Maslov et al., 2004; Luo et al., 2006) have indicated decreased number of NSCs with age.

Although neurogenesis is reduced in old animals, it can be increased or even restored to adult levels by enriched environment (Kempermann et al., 2002), infusion of growth factors (Jin et al., 2003), or stroke (Jin et al., 2004; Darsalia et al., 2005). Seizure-induced enhancement of neurogenesis is not altered between 1 and 3 months of age (Gray et al., 2002), but a recent study (Rao et al., 2008) reported lack of increased neurogenesis in response to seizures in aged ( 24 months old) rats. Together, available data indicate that aged NSCs retain the ability to respond to extrinsic cues similar to NSCs in adult animals, which is important in the perspective of a potential future therapeutic use of neuronal replacement from endogenous NSCs in human neurodegenerative disorders (Lindvall and Kokaia, 2008), which mainly affect older people. Recently, Morgenstern et al. (2008) reported that despite a sharp decline in hippocampal neurogenesis in aged mice, the density of dendritic spines in the new neurons was similar to that observed in young adult animals. These findings suggest that the age-related mechanisms leading to reduced neurogenesis do not affect the morphological properties of the new neurons. However, very little is known about the influence of aging on the intrinsic properties of NSCs and the functional characteristics of their neuronal progeny.

The aims of the present study were twofold: First, to explore whether the age-related decline of neurogenesis is associated with changes in numbers and gene expression of NSCs in SVZ; Second, to determine the intrinsic properties of NSCs and their progeny in aged compared with embryonic and adult mice. Using NSCs from embryonic LGE and adult and aged SVZ, we show 
that the age-dependent reduction in neurogenesis is accompanied by loss of NSCs and decreased expression of NSC markers and developmentally important transcription factors. However, the aged NSCs can proliferate, differentiate along all neural lineages, and produce functional neurons in vitro, similar to their adult counterparts, although with lower efficacy.

\section{Materials and Methods}

Animals. Embryonic (E13.5, day of vaginal plug detection designated as E0.5), adult (3-5 months), and aged (22-26 months) C57BL6 (B\&K Universal) and nestin-green fluorescent protein (GFP; gift from Dr. G. Enikolopov, Cold Spring Harbor Laboratory, Cold Spring Harbor, NY) mice were bred at Lund University Biomedical Center. All experimental procedures were approved by the Malmö-Lund ethical committee.

Bromodeoxyuridine administration. Mice were given bromodeoxyuridine (BrdU; $50 \mathrm{mg} / \mathrm{kg}$, i.p.), dissolved in potassium PBS (KPBS), four times with $2 \mathrm{~h}$ interval, and were killed $2 \mathrm{~h}$ thereafter.

Immunohistochemistry. Animals received an overdose of sodium pentobarbital and were transcardially perfused with saline followed by icecold $4 \%$ paraformaldehyde (PFA) in 0.1 м KPBS. Brains were removed, postfixed overnight, and placed in $20 \%$ sucrose in $0.1 \mathrm{~m}$ phosphate buffer for $24 \mathrm{~h}$. Coronal sections $(30 \mu \mathrm{m})$ were cut on a freezing microtome and stored in cryoprotective solution. Free-floating sections were preincubated in $0.25 \%$ Triton X-100 in KPBS containing 5\% appropriate secondary serum for $1 \mathrm{~h}$. Sections were then incubated with primary antibodies overnight at $4^{\circ} \mathrm{C}$. Primary antibodies included the following: rat anti-BrdU (1:100; Sigma), rabbit anti-phosphorylated histone $3(\mathrm{p}-\mathrm{H} 3)$ (1:400; Millipore), goat anti-doublecortin (Dcx) (1:400; Santa Cruz Biotechnology), rabbit anti-Sox2 (1:500; Millipore Bioscience Research Reagents), and rabbit anti-Gsh2 (1:2500; gift from Dr. Kenneth Campbell, University of Cincinnati, Cincinnati, $\mathrm{OH})$. For BrdU staining, DNA was denatured in $\mathrm{HCl}$ for $30 \mathrm{~min}$ at $65^{\circ} \mathrm{C}$. For Sox 2 staining, heat-induced (microwave) epitope retrieval in citrate buffer, $\mathrm{pH}$ 6.0, was used. After overnight incubation, sections were rinsed and incubated in darkness for $2 \mathrm{~h}$ with Cy3-conjugated donkey anti-rat, donkey anti-rabbit, and donkey anti-goat antibodies (1:200; Jackson ImmunoResearch). Nestin$\mathrm{GFP}+$ cells were visualized by endogenous GFP fluorescence and counterstained using TO-PRO-3 nuclear marker (Invitrogen). For doublelabel immunohistochemistry with BrdU and Sox2, free-floating sections were denatured in $\mathrm{HCl}$ and incubated with both primary antibodies overnight as described above. Sections were then rinsed and incubated in darkness for $2 \mathrm{~h}$ with Cy3-conjugated donkey anti-rat and biotinylated donkey anti-rabbit antibodies. Biotinylated antibodies were visualized by incubating sections with streptavidin-Alexa 488 (Invitrogen) for $2 \mathrm{~h}$ at room temperature. For BrdU and Dcx double-label immunohistochemistry, sections were incubated first with goat anti-Dcx antibody overnight. Then sections were incubated with biotinylated donkey anti-goat, streptavidin-Alexa 488, fixed in PFA for $20 \mathrm{~min}$ at room temperature, and BrdU immunostaining was performed.

After final washing, sections were mounted on glass slides and coverslipped with glycerol-based mounting medium. When needed, autofluorescence eliminator reagent (Millipore Bioscience Research Reagents) was used to reduce lipofuscin autofluorescence in aged tissue.

Microscopical analysis. All assessments were performed by a blinded observer. Immunostaining was examined using an Olympus BX61 fluorescence light microscope. Briefly, four coronal sections throughout the SVZ, located 0.74, 0.5, 0.14, and $0.02 \mathrm{~mm}$ anterior to bregma (Paxinos and Watson, 1997), were analyzed bilaterally. Stereological estimations of BrdU+, Dcx +, Sox $2+$, and nestin-GFP+ cells were performed with the optical fractionator method (Gundersen and Jensen, 1987) using an Olympus BX61 microscope $(\times 100$ objective), ColorView video camera, and CAST-GRID software (Olympus). For systematic sampling, the frame area was set to $1031.1 \mu \mathrm{m}^{2}$ with a step length of $80 \mu \mathrm{m}$ in $X$ and $Y$ directions and the optical dissector constituting a 5- $\mu \mathrm{m}$-thick fraction of the total section thickness. Because of their very low numbers in the aged brain, all p-H3 + and Gsh2+ cells were counted in the same sections as for the stereological estimations, and the total number of cells was calculated by multiplying with the total number of sections. Percentage of
Sox $2+$ and Dcx + cells colabeled with BrdU was estimated in $\sim 100$ cells in high magnification fields in the SVZ in four sections per brain.

Tissue dissection, cell isolation, and flow cytometry. Animals were deeply anesthetized using halothane and killed with cervical dislocation. Embryos or brains were removed and placed in ice-cold L-15 (Invitrogen). The brains of adult and aged animals were cut into 1-mm-thick coronal sections using a sectioning matrix. The LGEs of embryos were dissected, incubated in basic medium at $37^{\circ} \mathrm{C}$ for $15 \mathrm{~min}$, and mechanically dissociated into a single-cell suspension. The SVZ lining the lateral ventricle of adult and aged animals was dissected from the sections and enzymatically dissociated in HBSS with $0.015 \mathrm{M}$ Hepes, $5.4 \mathrm{mg} / \mathrm{ml} \mathrm{D}$-glucose, 1.33 $\mathrm{mg} / \mathrm{ml}$ Trypsin (Invitrogen), $80 \mathrm{U} / \mathrm{ml}$ DNase, $0.7 \mathrm{mg} / \mathrm{ml}$ hyaluronidase, and $0.2 \mathrm{mg} / \mathrm{ml}$ kynurenic acid (Sigma) at $37^{\circ} \mathrm{C}$ for $30 \mathrm{~min}$. The cell suspension was purified on a sucrose gradient $(30 \%$ sucrose in $0.5 \times$ HBSS) followed by a BSA gradient (4\% BSA in Earle's balanced salt solution with $1 \mathrm{~m}$ Hepes). The GFP+ cells from LGE, SVZ, or cultures were sorted on a fluorescence-activated cell sorter, FACS DiVa (Becton Dickinson). An initial gate based on forward and side scatter was set to exclude debris and cell aggregates, 7AAD was used to exclude dead cells. A sorting gate was set around the main GFP + population, at least $1 \log$ higher than GFP - controls. Sorted cells were processed for cell culture or RNA isolation as described below.

Cell culture. Neurospheres were grown in DMEM/F12 supplemented with B27, 0.6\% glucose (Sigma), 2 mm Glutamax, 1.125\% sodium bicarbonate, $15 \mathrm{~mm}$ Hepes, and $0.05 \mathrm{mg} / \mathrm{ml}$ Gentamycin (Basic Medium). For proliferative conditions, $20 \mathrm{ng} / \mathrm{ml}$ epidermal growth factor, $10 \mathrm{ng} / \mathrm{ml}$ basic fibroblast growth factor (R\&D Systems), and $2 \mu \mathrm{g} / \mathrm{ml}$ Heparin (Sigma) was added (proliferative medium). For neurosphere assays, cells were grown at 10 cells $/ \mu$ in uncoated cell culture flasks for $7 \mathrm{~d}$. For counting, spheres were transferred to 48 -well plates with grids. Bulk cultures were grown at $20-50$ cells/ $\mu$ l. Neurospheres were fed every other day and passaged every week using accutase (PAA Laboratories).

For differentiation and electrophysiological measurements, neurospheres were plated in proliferative medium overnight on poly-D-lysine (PDL) laminin (Sigma)-coated coverslips or chamberslides (Nunc). After overnight incubation (proliferative state), medium was changed to basic medium supplemented with N2 and 1\% FBS and cells were let to differentiate for 7-14 d (differentiated state). All reagents were from Invitrogen, if not otherwise stated.

For in vitro proliferation, cells were grown in 96-well plates, and total cell number was assessed at $0,2,4$, and $6 \mathrm{~d}$ in vitro (DIV) using 3-(4,5dimethylthiazyl)2,5-diphenyltetrazolium bromid (MTT) test (Roche) with absorbance at $450 \mathrm{~nm}$.

For survival assays, cells were grown under proliferative or differentiation conditions on PDL/laminin-coated coverslips. Levels of apoptosis were measured by TUNEL staining using in situ cell death detection kit, Peroxidase (Roche), according to the manufacturer's instructions but combined with Hoechst. The number of TUNEL+ cells with fragmented and/or condensed nuclei was counted and expressed as percentage of total number of Hoechst + cells.

For senescence-associated $\beta$-galactosidase (SA- $\beta$-gal) staining, embryonic, adult, and aged neurospheres were plated on PDL/laminincoated coverslips overnight and then fixed with PFA. Staining was performed using the Senescence Cells Histochemical Staining Kit (Sigma) according to manufacturer's guidelines, and cells were counterstained using Hoechst.

For immunocytochemistry, cells grown on chamberslides or glass coverslips were fixed in 4\% PFA for 15 min (for GABA and glutamate staining, $0.2 \%$ glutaraldehyde in $4 \%$ PFA was used) and processed as described above. Primary antibodies were mouse anti- $\beta$-III-tubulin (Sigma; 1:350), rabbit anti-GFAP (Dako; 1:1000), mouse anti-CNPase (Sigma; 1:100), rabbit anti-GABA (Sigma; 1:2000), rabbit anti-glutamate (Millipore Bioscience Research Reagents; 1:100), and rabbit anti-GFP (Abcam; 1:1000). After washing, appropriate Cy3-conjugated secondary antibodies, including goat-anti mouse, goat-anti rabbit, donkey-anti mouse, and donkey-anti rabbit antibodies, were applied for $1 \mathrm{~h}$ at room temperature. Biocytin-injected cells were visualized using streptavidinAlexa 488 (Invitrogen) for $1 \mathrm{~h}$ at room temperature. Cell nuclei were counterstained using Hoechst (Invitrogen). 
A

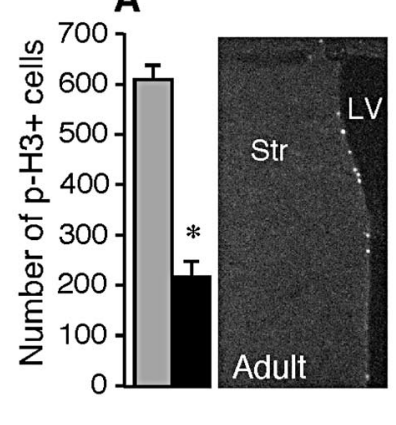

B

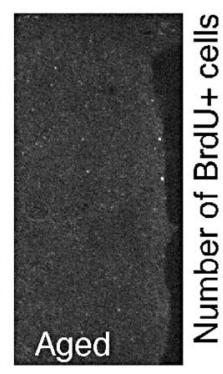

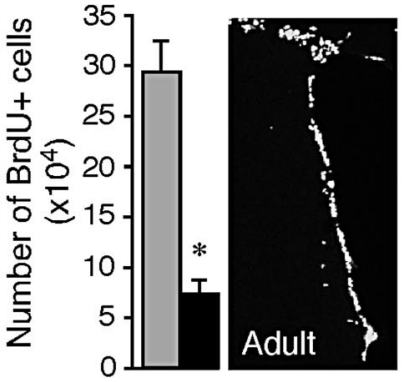

C

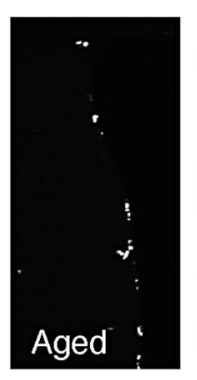

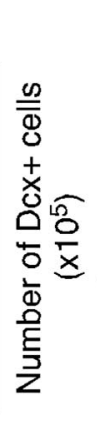

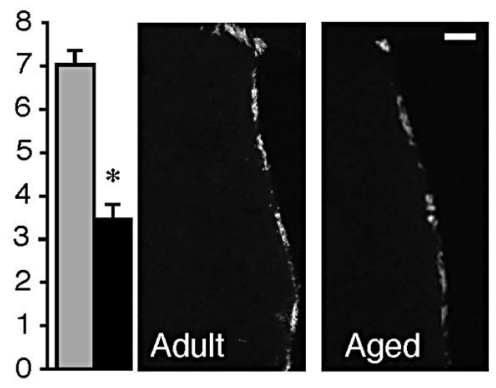

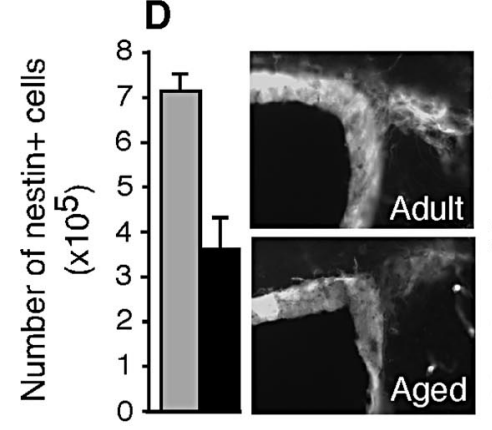

E

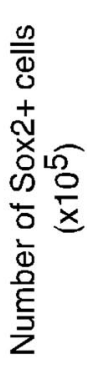

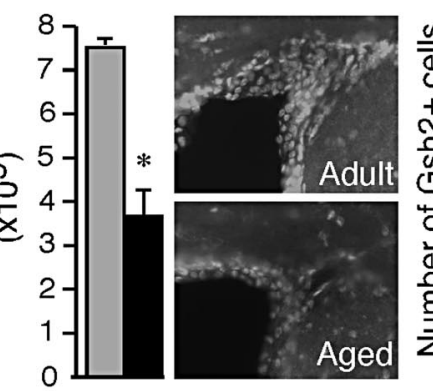
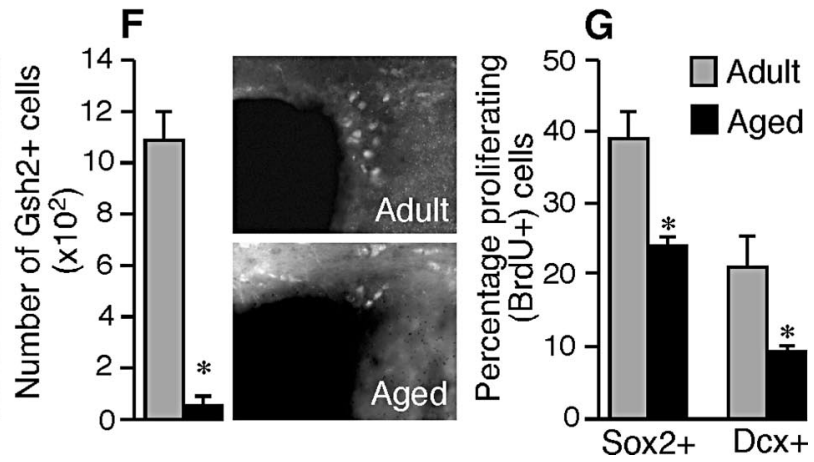

Figure 1. Aging causes severe reduction of in vivo neurogenesis and loss of NSCS in SVZ. $A-G$, Proliferation as assessed by number of p-H3 $+(\boldsymbol{A})$ and BrdU $+(\boldsymbol{B})$ cells, neuroblast formation $(\boldsymbol{C})$ as assessed by Dcx + cells, number of NSCs as assessed by number of nestin-GFP + cells $(\boldsymbol{D})$, and number of cells expressing the putative markers Sox2 $(\boldsymbol{E})$ and Gsh2 $(\boldsymbol{F})$, and proliferative activity in NSCs and neuroblasts as assessed by the percentage BrdU +/Sox2 + and BrdU +/Dcx + cells of the total number of Sox $2+$ and Dcx $+(G)$ cells, respectively, in adult and aged SVZ. Means \pm SEM; $n=6$ and $4(\boldsymbol{A}-\boldsymbol{C}$ and $\boldsymbol{E}, \boldsymbol{F}), n=6$ and $3(\boldsymbol{D})$, and $n=5$ and $6(\boldsymbol{G})$ for adult and aged, respectively. ${ }^{*} p<0.05$, one-way ANOVA with Fisher's post hoc test. Scale bars: $\boldsymbol{A}-\boldsymbol{C}, 100 \mu \mathrm{m} ; \boldsymbol{D}, \boldsymbol{E}, 30 \mu \mathrm{m}$.

$R N A$ isolation, reverse transcriptase-PCR, and quantitative PCR. Ten thousand GFP + cells were sorted directly into RLT lysis buffer (Qiagen) and frozen at $-80^{\circ} \mathrm{C}$. RNA was isolated using RNAeasy micro (Qiagen) with DNase treatment according to the manufacturer's guidelines. RNA was reverse transcribed using oligoDT primers and superscript-II (Invitrogen). Quantitative PCR (Q-PCR) was performed with TaqMan universal master mix and TaqMan Gene expression assays (supplemental Table 1, available at www.jneurosci.org as supplemental material). cDNA from 150 cells was used for each Q-PCR, and all experiments were run in triplicate. cDNA input was normalized to glyceraldehyde-3-phosphate dehydrogenase (GAPDH). Relative gene expression was calculated using the $\Delta \Delta \mathrm{CT}$ method. Results are means from two to four individual experiments.

Electrophysiology. All measurements were performed in aCSF solution ( $\mathrm{pH}=7.4$ and $290 \mathrm{mOsm}$ ) containing (in $\mathrm{mm}$ ) $119 \mathrm{NaCl}, 2.5 \mathrm{KCl}, 1.3$ $\mathrm{MgSO}_{4}, 1 \mathrm{NaH}_{2} \mathrm{PO}_{4}, 26 \mathrm{NaHCO}_{3}, 2.5 \mathrm{CaCl}_{2}$, and 11 glucose. The internal solution used to record intrinsic membrane properties and voltagegated potassium channel kinetics contained (in mM) $122.5 \mathrm{~K}$-gluconate, $17.5 \mathrm{KCl}, 10 \mathrm{KOH}-\mathrm{HEPES}, 0.2 \mathrm{KOH}-\mathrm{EGTA}, 2 \mathrm{MgATP}, 0.3 \mathrm{Na}_{3} \mathrm{GTP}$, and $8 \mathrm{NaCl}(\mathrm{pH}=7.2$ and $300 \mathrm{mOsm})$. Potassium currents were measured in the presence of $1 \mu \mathrm{M}$ tetrodotoxin (TTX) to block sodium channels. When sodium channel kinetics was investigated, potassium was replaced by cesium in the internal solution, and $20 \mathrm{~mm}$ tetraethylammonium chloride (TEA) and $2 \mathrm{~mm} 4$-aminopyridine (4AP) were added to the bath solution. To measure EPSCs, we used an internal solution, $\mathrm{pH}=$ 7.2 , containing (in $\mathrm{mm}$ ) $117.5 \mathrm{Cs}$-gluconate, $17.5 \mathrm{CsCl}$, $10 \mathrm{CsOH}-$ HEPES, 0.2 CsOH-EGTA, 2 MgATP, $0.3 \mathrm{Na} 3 \mathrm{GTP}, 8 \mathrm{NaCl}$, and 5 QX314, and $100 \mu \mathrm{M}$ glutamate was added to the external solution. To measure IPSCs, Cs-gluconate was replaced by $\mathrm{CsCl}$, and $100 \mu \mathrm{M}$ GABA was added to the external solution. In some experiments, the internal solution contained $0.05 \%$ biocytin for later identification of recorded cells.

All recordings were performed at room temperature using the wholecell patch-clamp technique (Hamill et al., 1981). Pipettes were pulled from borosilicate glass and had a resistance of 3-6 M $\Omega$ when filled with internal solution. Data were filtered at $2.9 \mathrm{kHz}$ and sampled at $10 \mathrm{kHz}$ with EPC9 amplifier (HEKA Electronik) and stored on a G4 Macintosh computer. Off-line analysis was performed using IgorPro (version 5.02, WaveMetrics) and FitMaster (version 2.05, HEKA Electronik). Leak currents were subtracted online. Capacitive transients were compensated using the circuitry of the patch-clamp amplifier. Cell capacitance was measured shortly after establishing the whole-cell configuration. Subsequently, the current-clamp configuration was used to measure resting membrane potential. The input resistance was calculated as the slope of the linear fit to the current-voltage curve resulting from $500 \mathrm{~ms}$ current injections of -15 to $0 \mathrm{pA}$ in $5 \mathrm{pA}$ increments. Current densities were expressed as the ratio between maximal current amplitude and wholecell membrane capacitance $(\mathrm{pA} / \mathrm{pF})$ at given voltage depolarizations. Action potentials (APs) were elicited by $500 \mathrm{~ms}$ current injections in 10 or $20 \mathrm{pA}$ increments, and threshold, amplitude, duration, and afterhyperpolarization of the first AP were analyzed. Duration of AP was measured between the fast upstroke and downstroke at the $50 \%$ level of maximal amplitude.

Total potassium currents $\left(I_{\mathrm{K}(\mathrm{DR}+\mathrm{A})}\right)$ were elicited by a voltage protocol comprising $200 \mathrm{~ms}$ prepulses of $-110 \mathrm{mV}$ followed by $200 \mathrm{~ms}$ voltage steps from -70 to $+60 \mathrm{mV}$ in $10 \mathrm{mV}$ increments. Delayed rectified potassium currents $\left(I_{\mathrm{K}(\mathrm{DR})}\right)$ were isolated using a $-40 \mathrm{mV}$ prepulse to inactivate A-type potassium channels $\left(I_{\mathrm{K}(\mathrm{A})}\right) . I_{\mathrm{K}(\mathrm{A})}$ was obtained subtracting $I_{\mathrm{K}(\mathrm{DR})}$ for $I_{\mathrm{K}(\mathrm{DR}+\mathrm{A})}$. Measured currents $(I)$ were divided by current maxima $\left(I_{\max }\right)$ to obtain normalized values. Blockers affinities were estimated using $20 \mathrm{~mm}$ TEA or $2 \mathrm{~mm} 4 \mathrm{AP}$ and a prepulse of $-110 \mathrm{mV}$ followed by a depolarizing step at $+40 \mathrm{mV}$. Sodium currents were elicited by $10 \mathrm{~ms}$ voltage steps from -60 to $+60 \mathrm{mV}$ in $10 \mathrm{mV}$ increments. To characterize the voltage dependence of inactivation, the conductance $(G)$ at each command voltage was put in relation to the maximal conductance $G_{\max }$. The conductance was calculated as $G=I /\left(E-E_{\mathrm{rev}}\right)$, where $G$ is the conductance, $I$ the measured current, $E$ the applied voltage, and $E_{\text {rev }}$ the reversal potential for $\mathrm{Na}^{+}$. Using Nerst equation, we calculated the reversal potential for $\mathrm{Na}^{+}$to be $+74 \mathrm{mV}$. The inactivation kinetics were studied using a prepulse protocol with conditioning steps to membrane potentials between -110 and $-40 \mathrm{mV}$ for $200 \mathrm{~ms}$ followed by a $10 \mathrm{~ms}$ voltage step at $0 \mathrm{mV}$.

Occurrence of functional glutamate and GABA receptors was assessed 
by adding $100 \mu \mathrm{M}$ glutamate or $100 \mu \mathrm{M}$ GABA to the bath solution for $15-20 \mathrm{~s}$ by switching the perfusion medium. Excitatory and IPSCs were measured in the presence of $100 \mu \mathrm{m}$ picrotoxin (PTX) and $10 \mu \mathrm{M} 2,3$ dihydroxy-6-nitro-7-sulfonyl-benzo[f] quinoxaline (NBQX) together with $50 \mu \mathrm{M}$ D-AP5, respectively.

In all voltage-clamp experiments, the holding potential was $-70 \mathrm{mV}$. Liquid junction potentials were not compensated.

Statistical analysis. Comparisons were performed using one-way ANOVA followed by Fisher's post hoc test or repeated-measures ANOVA. Data are presented as means \pm SEM, and differences are considered significant at $p<0.05$.

\section{Results}

Reduction in cell proliferation and neuroblast formation and loss of stem/progenitor cells in aged subventricular zone We initially investigated in vivo cell proliferation in the SVZ of adult and aged mice. To label all proliferating cells over an $8 \mathrm{~h}$ period, BrdU was injected four times, $2 \mathrm{~h}$ apart, and mice were perfused $2 \mathrm{~h}$ thereafter. Sections were stained against BrdU and the proliferation marker $\mathrm{p}-\mathrm{H} 3$, which visualizes cells in active mitosis at the time of perfusion. We found 65 and $79 \%$ decrease in the number of p-H3 + and BrdU + cells, respectively, in the aged compared with the adult SVZ (Fig. $1 A, B$ ). These findings with two different markers show that SVZ cell proliferation is markedly decreased in aged animals.

Next, we analyzed the formation of neuroblasts in the adult and aged SVZ. Sections were stained with an antibody against Dcx, a microtubule-associated protein transiently expressed in neuroblasts up to 4 weeks after their formation (Brown et al., 2003). We found $49 \%$ reduction in the number of Dcx + cells in SVZ of aged animals compared with adult ones (Fig. 1C). Thus, also the formation of neuroblasts has declined in the SVZ of aged animals.

To explore whether the reduced cell proliferation and neuroblast formation in SVZ of old animals were attributable to loss of NSCs, we analyzed the expression of markers that have been widely used to identify NSCs. The intermediate filament nestin (Lendahl et al., 1990) and the sry homeobox transcription factor Sox2 (Ellis et al., 2004) are expressed in NSCs both in the embryo and the adult SVZ. The homeodomain transcription factor Gsh2 is expressed in NSCs in LGE and adult SVZ, which give rise to striatal projection neurons and/or olfactory bulb interneurons, respectively (Stenman et al., 2003).

The number of nestin-GFP+, Sox $2+$, and Gsh $2+$ cells were determined in the adult and aged mouse SVZ. We detected reduced number of GFP + cells in the SVZ of aged nestin-GFP mice (Fig. $1 D$ ). The number of nestin-GFP + cells was $50 \%$ lower in aged compared with adult nestin-GFP mice (Fig. $1 D$ ). Strikingly, the number of Sox $2+$ cells was decreased by $49 \%$ (Fig. $1 E$ ) and the number of Gsh $2+$ cells by $96 \%$ in the SVZ of aged mice (Fig. $1 F)$. Together, these data indicate that aging leads to a loss of NSCs in the SVZ.

To identify which populations of cells in the SVZ decrease their proliferative activity during aging, we analyzed sections double stained for BrdU and markers for NSCs and neuroblasts, Sox 2 and Dcx, respectively. The percentage BrdU $+/$ Sox $2+$ and $\mathrm{BrdU}+/ \mathrm{Dcx}+$ cells of the total number of Sox $2+$ and Dcx + cells in SVZ was reduced, by 38 and 58\%, respectively, in aged compared with adult animals (Fig. $1 G$ ). These findings together with the decreased numbers of Sox $2+$ and Dcx + cells indicate that NSCs and neuroblasts contribute to the age-related reduction of cell proliferation in SVZ.
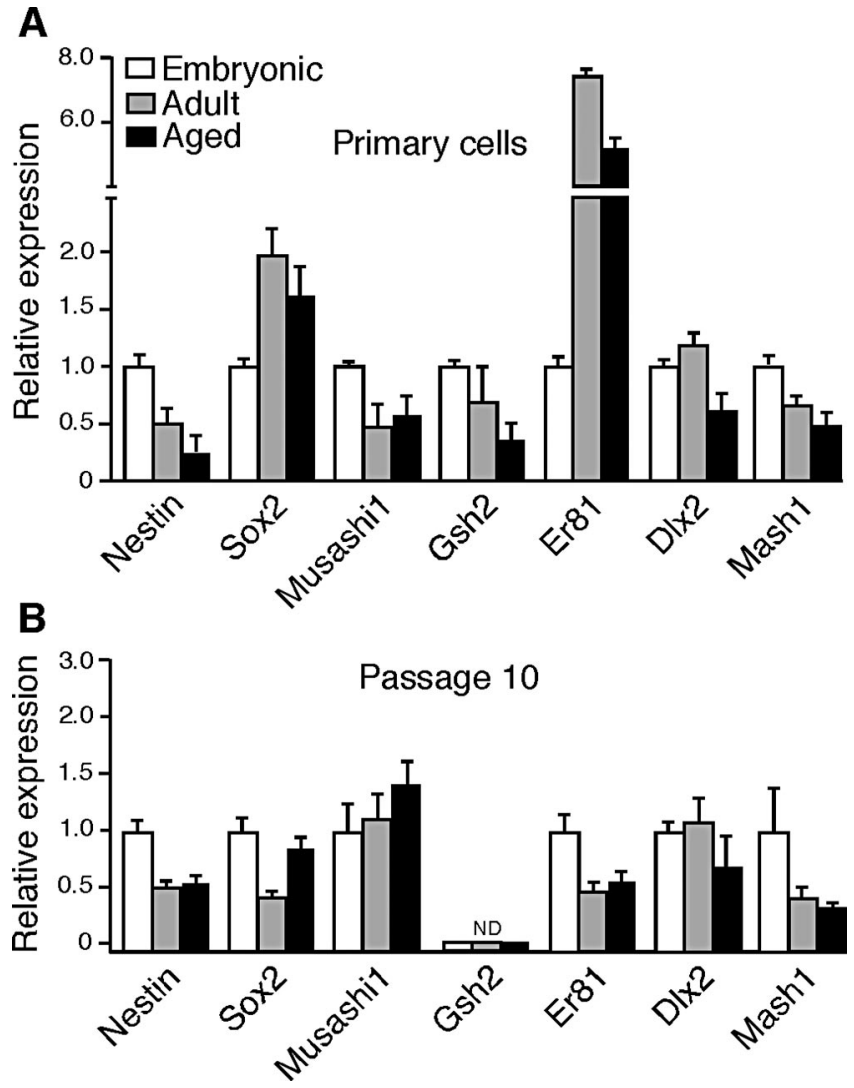

Figure 2. Aging causes reduction of NSC and neurogenic factor gene expression in SVZ stem/progenitor cells. $\boldsymbol{A}, \boldsymbol{B}$, Gene expression levels for stem/progenitor cell markers (nestin, Sox2, Musashi1), developmentally important transcription factors (Gsh2, Er81), and neurogenic factors (Dlx2, Mash1) measured using quantitative $P C R$ in primary $(\boldsymbol{A})$ or expanded $(\boldsymbol{B})$ nestinGFP + cells sorted from embryonic LGE, and adult and aged SVZ of nestin-GFP mice. Data are presented as relative expression normalized to GAPDH levels and compared with embryonic LGE levels (set at 1). Means from two to four individual experiments. ND, Not detected.

\section{Reduction in neural stem cell and neurogenic factor gene} expression in aged subventricular zone

To identify differences in intrinsic properties between NSCs from animals of various ages, we sorted nestin-GFP + cells from embryonic LGE and from adult and aged SVZ tissue. We isolated mRNA and by quantitative PCR compared the gene expression levels of known stem cell markers and neurogenic factors (Fig. 2A). Nestin gene expression decreased to 40 and 20\% of embryonic levels in adult and aged animals, respectively, whereas Sox2 expression was 50 and $41 \%$ higher (Fig. $2 A$ ). The RNA-binding protein Musashi 1 (Msi1) is expressed in NSCs, both during embryonic development and in adulthood (Sakakibara et al., 1996; Sakakibara and Okano, 1997). Expression of Msi1 was 60 and $50 \%$ lower and of Gsh 230 and 70\% lower in adult and aged animals, respectively, compared with embryonic levels (Fig. $2 \mathrm{~A}$ ). In the embryonic brain, the transcription factor Er81 is expressed in progenitors giving rise to olfactory interneurons, separating them from progenitors expressing Isl1, which generate striatal projection neurons. Er81 continues to be expressed in the postnatal SVZ, whereas Isl1 expression is lost. We found the expression of Er81 to be almost eightfold higher in adult SVZ NSCs compared with embryonic LGE cells. Interestingly, the expression of Er 81 decreased by $32 \%$ in aged compared with adult cells (Fig. 2A). In accordance to previous findings (Parmar et al., 2003), where no Isl1 protein expression could be found in the SVZ, we detected gene expression of Isll only in embryonic cells 
(data not shown). Thus, there is a switch in the fate of nestin + cells, from production of striatal projection neurons in the embryonic brain to generation of olfactory bulb interneurons in the adult brain, the latter process declining with age.

The proneural transcription factor Dlx2 is expressed in the embryonic LGE and in transit amplifying cells and neuroblasts in the adult mouse SVZ (Doetsch et al., 2002). Gene expression of Dlx2 was similar in adult and embryonic NSCs but was $42 \%$ lower in aged compared with adult cells (Fig. $2 A$ ). Also, the expression of another proneural factor, Mash1, was reduced but in both adult and aged cells by 40 and 50\%, respectively (Fig. $2 A$ ). To summarize, the most consistent pattern in our gene expression data is a decline in the levels of NSC markers, developmentally important transcription factors, and proneural genes in the aged SVZ.

To explore to what extent the changes in gene expression in SVZ NSCs during aging are attributable to environmental influences, we performed the same gene expression analysis on in vitro-expanded cells (Fig. $2 B$ ). Interestingly, the lower gene expression for nestin, Sox2, Gsh2, and Er81 in aged compared with adult primary SVZ cells was no longer observed after expansion. Expression of Gsh2 was lost in expanded cells from all ages (Fig. 2B). Moreover, Sox2 and Er81 gene expression, which was higher in primary adult and aged SVZ cells compared with embryonic LGE cells, was similar or lower after expansion. Conversely, the lower Msi1 gene levels in primary adult and aged SVZ cells were not detectable in expanded cells. These data show that several of the differences in gene expression between embryonic, adult, and aged NSCs observed in primary cells disappear during expansion and, therefore, most likely are attributable to environmental factors rather than intrinsic NSC properties.

\section{Aged neural stem cells proliferate slower but generate neurospheres and differentiate similar to adult ones after in vitro expansion}

We assessed neurosphere formation from NSCs in embryonic LGE and SVZ of adult and aged brain. The yield of primary neurospheres was markedly lower from both adult and aged SVZ than from LGE (61 and 69\% reduction, respectively) (Fig. 3A). Aged SVZ gave rise to $22 \%$ fewer primary neurospheres than adult SVZ. Moreover, although secondary neurosphere formation did not differ between embryonic LGE and adult SVZ, it was $28 \%$ less in aged compared with adult tissue. Interestingly, after expansion of neurospheres from embryonic LGE and adult or aged SVZ for 10 passages, we could not detect any differences between the groups in the number of generated neurospheres (Fig. 3A). We then wanted to investigate the neurosphereforming capacity of enriched NSCs isolated from embryonic LGE and adult and aged SVZ, and, therefore, sorted GFP+ cells from nestin-GFP mice. In accordance with the findings in nonsorted, wild-type cells (Fig. 3A), we found that the yield of primary neurospheres was 77 and $80 \%$ lower from sorted adult and aged cells, respectively, compared with embryonic NSCs (Fig. 3B). Surprisingly, we found no differences between the groups in secondary neurosphere formation or in number of neurospheres after 10 passages (Fig. 3B). When we plated GFP - cells under the same conditions as GFP + cells, they failed to form even single neuro- spheres (data not shown). Together, our findings indicate that SVZ in adult and, in particular, aged mice contains fewer NSCs with neurosphere-forming capacity compared with embryonic LGE. However, after expansion and sorting, NSCs from all age groups have the same potential for neurosphere formation.

Next, we compared the in vitro proliferation capacity of NSCs from the different groups. Cells from embryonic LGE and adult and aged SVZ proliferated and were expanded for at least 15 passages without any obvious signs of senescence (data not shown). The rate of proliferation was measured at $0,2,4$, and 6 DIV using the MTT assay (Fig. 4A). Repeated-measures ANOVA revealed progressive increase of cell numbers with time in all three groups. However, the magnitude of the increase differed between the groups with embryonic showing the highest and aged NSCs the lowest rate of proliferation.

We also assessed the apoptotic death of NSCs of different origins. Under proliferating conditions, we found no differences in the number of apoptotic, TUNEL+ cells between neurospheres from embryonic LGE and adult and aged SVZ (Fig. 4B). Under differentiating conditions, there was a trend toward increased apoptosis with age, and the number of TUNEL + cells was significantly higher with aged compared with embryonic NSCs (Fig. 4B)

One possible explanation to the age-related decline in neurogenesis could be that aged NSCs go into senescence. To test this hypothesis, we studied the expression of several cyclindependent kinase inhibitors implicated in senescence and cell cycle arrest in sorted primary nestin-GFP + cells from the LGE, and adult and aged SVZ, as well as in neurospheres expanded from the corresponding cells. Furthermore, we measured SA- $\beta$ gal activity, an indicator of replicative senescence, in NSCs from all ages expanded as neurospheres. In contrast to previous reports (Molofsky et al. 2006), we could not detect $p 16^{I N K 4 A}$ in primary cells of any age group (Fig. $4 C$ ). The expression of $p 19^{A R F}$ was higher in adult and aged SVZ cells, compared with embryonic SVZ cells. Expression of $p 21^{\text {Cipl } 1}$ was undetectable in aged SVZ cells but sevenfold higher in adult compared with embryonic SVZ cells. Interestingly, levels of $p 27^{K i p 1}$ increased progressively with age (Fig. 4C). After in vitro expansion of NSCs as neurospheres, expression of $p 16^{I N K 4 A}$ was detected in all age groups (Fig. $4 D$ ). The levels in adult and aged cells were 3.7- and 3.6-fold higher, respectively, than in embryonic cells. In contrast, levels of $p 19^{A R F}$ were lower in adult and aged cells. Expression of $p 21^{\text {Cipl }}$ was 20 and $80 \%$ higher, whereas levels of $p 27^{\text {Kip } 1}$ was 21 and $25 \%$ lower 
A

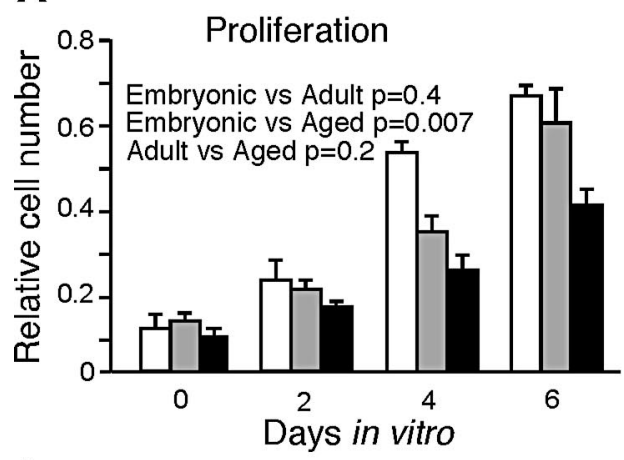

C

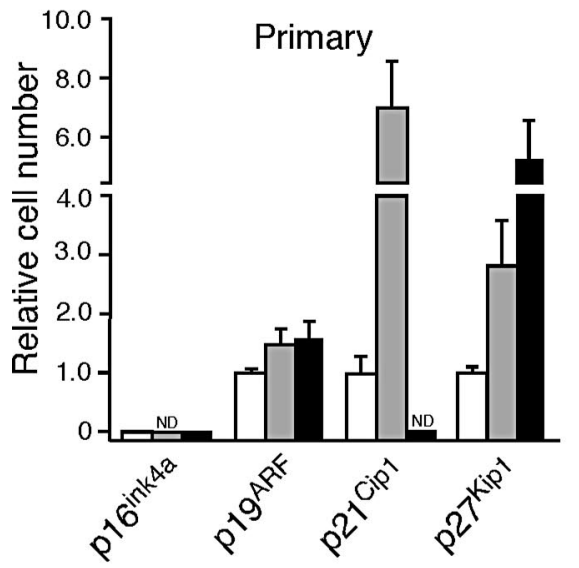

E
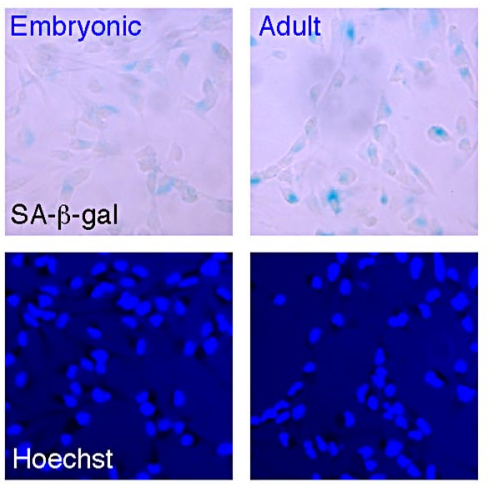

B

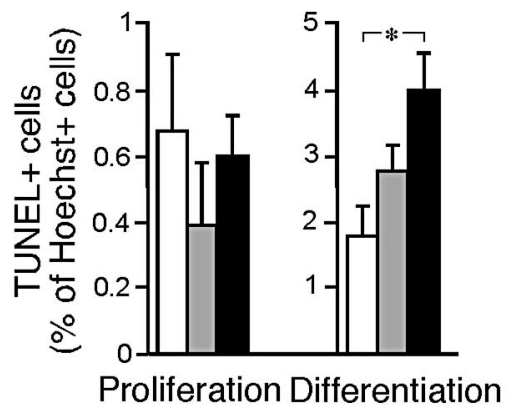

D
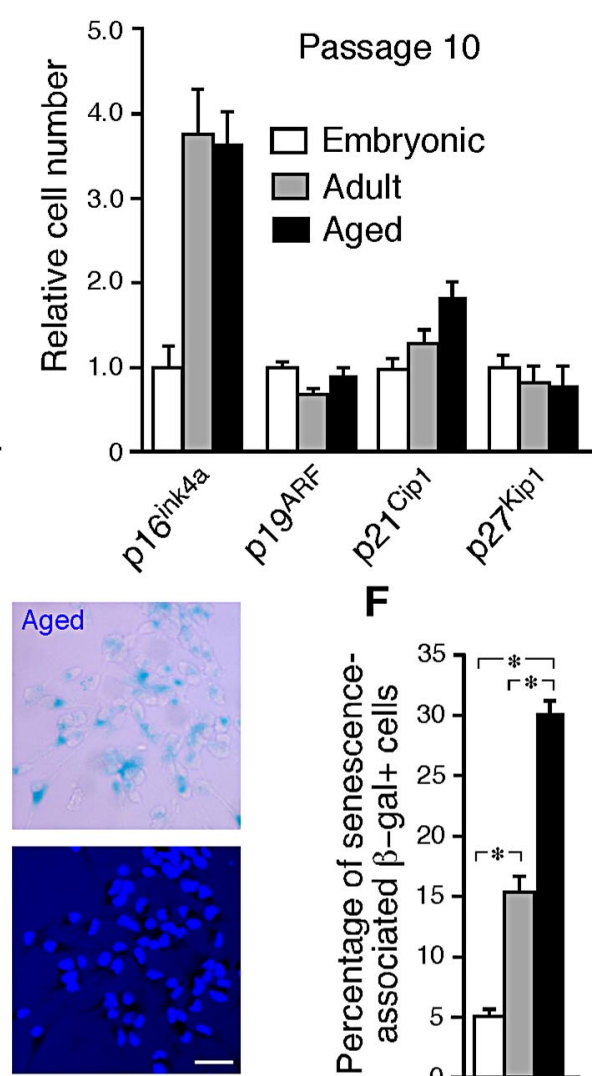

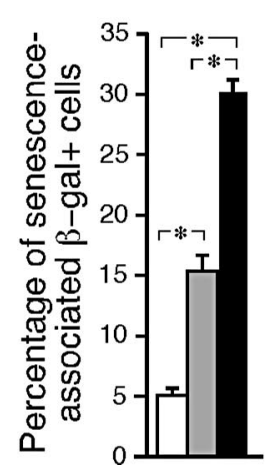

Figure 4. Aging causes reduction of NSC proliferation and survival during differentiation in vitro. Neurosphere cells were grown under proliferative and differentiating conditions. $A$, Relative number of cells assessed by MTT test. Proliferation was significantly higher in embryonic compared with adult NSCs and in adult compared with aged NSCS at 0, 2, 4, and 6 DIV. Means \pm SEM; ${ }^{*} p<$ 0.05 , repeated-measures ANOVA. Four independent cultures were used for quantification. $\boldsymbol{B}$, Survival assessed by numbers of TUNEL + apoptotic cells under proliferative (at 4 DIV) or differentiating conditions (at 7 DIV). Means \pm SEM. Four independent cultures were used for quantification. $\boldsymbol{C}, \boldsymbol{D}$, Expression of genes involved in senescence in primary $(\boldsymbol{C})$ and expanded (D) NestinGFP + sorted cells. $\boldsymbol{E}, \boldsymbol{F}$, Photomicrograph $(\boldsymbol{E})$ and percentage $(\boldsymbol{F})$ of neurosphere cells, from the different age groups, expressing SA- $\beta$-gal. Mean $\pm S E M$. Four independent cultures were used for quantification. ${ }^{*} p<0.05$, one-way ANOVA with Fisher's post hoc test. Scale bar, $30 \mu \mathrm{m}$. ND, Not detected.

in adult and aged cells, respectively, compared with embryonic levels (Fig. 4D). Analysis of SA- $\beta$-gal activity revealed a progressive increase with age (Fig. $4 E, F$ ). The percentage of neurosphere cells expressing SA- $\beta$-gal increased from $5 \%$ in embryonic cells to $15 \%$ in adult and $30 \%$ in aged cells (Fig. $4 F$ ). Together, our data indicate that NSCs in SVZ exhibit an age-dependent increase of gene expression for senescence markers in vivo and in vitro and of age-dependent replicative senescence in vitro.

To evaluate the differentiation potential of NSCs from various ages, we withdrew growth factors and added serum and N2 sup- plements to the culture medium. Cells were let to mature for 1 week and then stained with markers for neurons ( $\beta$-IIItubulin), astrocytes (GFAP), and oligodendrocytes (CNPase). In all age groups, the majority of cells differentiated into GFAP + cells with mature astrocytic morphology (Fig. 5A). A small fraction of the cells became CNPase+ with typical oligodendrocytic morphology. All age groups also generated $\beta$-III-tubulin + cells with multipolar processes and morphological characteristics of neurons (Fig. 5A). Thus, the multipotency and capacity to generate cells of all three neural lineages is maintained in aged brain. We assessed the neurogenic potential of these neurosphere cultures in more detail by quantifying the number of $\beta$-III-tubulin + cells formed from the different age groups. We found that embryonic LGE cells gave rise to 125 and $101 \%$ more $\beta$-III-tubulin + cells than adult and aged SVZ cells, respectively. However, there were no differences between adult and aged NSCs in the formation of neurons (Fig. 5B). To explore if NSCs of all age groups generated different subtypes of neurons, neurosphere cells were differentiated for 2 weeks and cultures then stained for GABA and glutamate. We found that embryonic, adult, and aged neurospheres generated cells with mature neuronal morphology and that a fraction of these cells were GABA+ or glutamate+ (Fig. 5C).

Adult and aged neural stem cells generate functional neurons in vitro, albeit at reduced frequency compared with embryonic cells

Whole-cell patch-clamp recordings showed that proliferating and differentiating cells from all ages exhibited similar input resistance and resting membrane potential with no significant differences related to age or degree of cell differentiation (Table 1).

The membrane capacitance was significantly higher in the proliferating adult compared with embryonic cells. After morphological differentiation, the membrane capacitance almost doubled in all groups. As determined in the currentclamp mode of the patch-clamp technique, none of the proliferating embryonic $(n=16)$ or aged cells $(n=13)$ fired AP in response to current injections, whereas 2 of 13 adult cells fired immature AP (Fig. $6 A$ ). In 7 of 20 adult proliferating NSC cells, we identified a small inward, fast-inactivating current, of 200$500 \mathrm{pA}$, which seemed to have the characteristics of sodium currents. Moreover, 2 of 21 aged, proliferating SVZ cells had large sodium currents of 1 and $6 \mathrm{nA}$, respectively (data not shown). After 2 weeks of differentiation, $88 \%$ of the neurons with mature morphology from embryonic NSCs fired mature and 12\% fired 
immature APs during membrane depolarization (Fig. 6B). Aging lead to decreased percentage of differentiated cells that fired APs and increased the percentage that did not, from 58 and 26\%, respectively, in adult group to 26 and $60 \%$, respectively, in aged group (Fig. $6 \mathrm{~B}$ ). The percentage of differentiated cells firing immature APs was similar in all groups (12-16\%) (Fig. $6 B)$.

The properties of APs did not differ between cells from various groups (Table 1). They were completely blocked by $1 \mu \mathrm{M}$ TTX, and were elicited with current injections of $10-20 \mathrm{pA}$. However, the relatively long duration and low amplitude of action potentials indicate that the cells most likely are still not functionally fully mature. A distinctive feature of differentiated neurons was the presence of a fast-inactivating inward current with the characteristics of $\mathrm{Na}^{+}$current (Fig. 6C). The current showed a peak between -20 and $10 \mathrm{mV}$ and an average maximum density of $97 \pm$ $19 \mathrm{pA} / \mathrm{pF}(n=6), 105 \pm 16 \mathrm{pA} / \mathrm{pF}(n=7)$, and $181 \pm 37 \mathrm{pA} / \mathrm{pF}(n=7)$ in neurons differentiated from embryonic, adult, and aged NSCs, respectively. We did not find any differences in activation and inactivation kinetics of $\mathrm{Na}^{+}$channels between neurons derived from the different groups (data not shown).

To identify other ion channels underlying active membrane properties, we performed voltage-clamp experiments. In proliferating cells, we identified the outward current (Fig. 7A) composed of two $\mathrm{K}^{+}$channel populations: a non-inactivating delayedrectified current $\left(I_{\mathrm{K}(\mathrm{DR})}\right)$ that constitutes most of the total $\mathrm{K}^{+}$current, and a fastinactivating A-type $\mathrm{K}^{+}$current $\left(I_{\mathrm{K}(\mathrm{A})}\right)$. There was higher percentage in adult and aged NSCs compared with embryonic ones for A-type current (Fig. 7B) but not for delayed-rectified current (Fig. 7C). Interestingly, total $\mathrm{K}^{+}$current density increased with age of NSC source (Fig. 7D). Thus, the total $\mathrm{K}^{+}$current density calculated at $+60 \mathrm{mV}$ increased with age, being $239 \pm 18 \mathrm{pA} / \mathrm{pF}(n=19), 296 \pm 15 \mathrm{pA} / \mathrm{pF}$ $(n=20)$, and $386 \pm 36 \mathrm{pA} / \mathrm{pF}(n=21)$ in LGE, adult, and aged NSCs, respectively. Differentiating cells of all age groups exhibited robust outward $\mathrm{K}^{+}$currents consisting of $I_{\mathrm{K}(\mathrm{DR})}$ and $I_{\mathrm{K}(\mathrm{A})}$. In contrast to proliferating conditions, we observed that the distribution of $I_{\mathrm{K}(\mathrm{DR})}$ and $I_{\mathrm{K}(\mathrm{A})}$ and total $\mathrm{K}^{+}$current density were similar in the three groups (data not shown). However, we found decreased $\mathrm{K}^{+}$current density of $191 \pm 23 \mathrm{pA} / \mathrm{pF}(n=$ $12), 207 \pm 27 \mathrm{pA} / \mathrm{pF}(n=9)$, and $155 \pm 22 \mathrm{pA} / \mathrm{pF}(n=9)$ in neurons differentiated from embryonic, adult, and aged NSC cells, respectively, compared with the proliferating conditions.

A

B

C
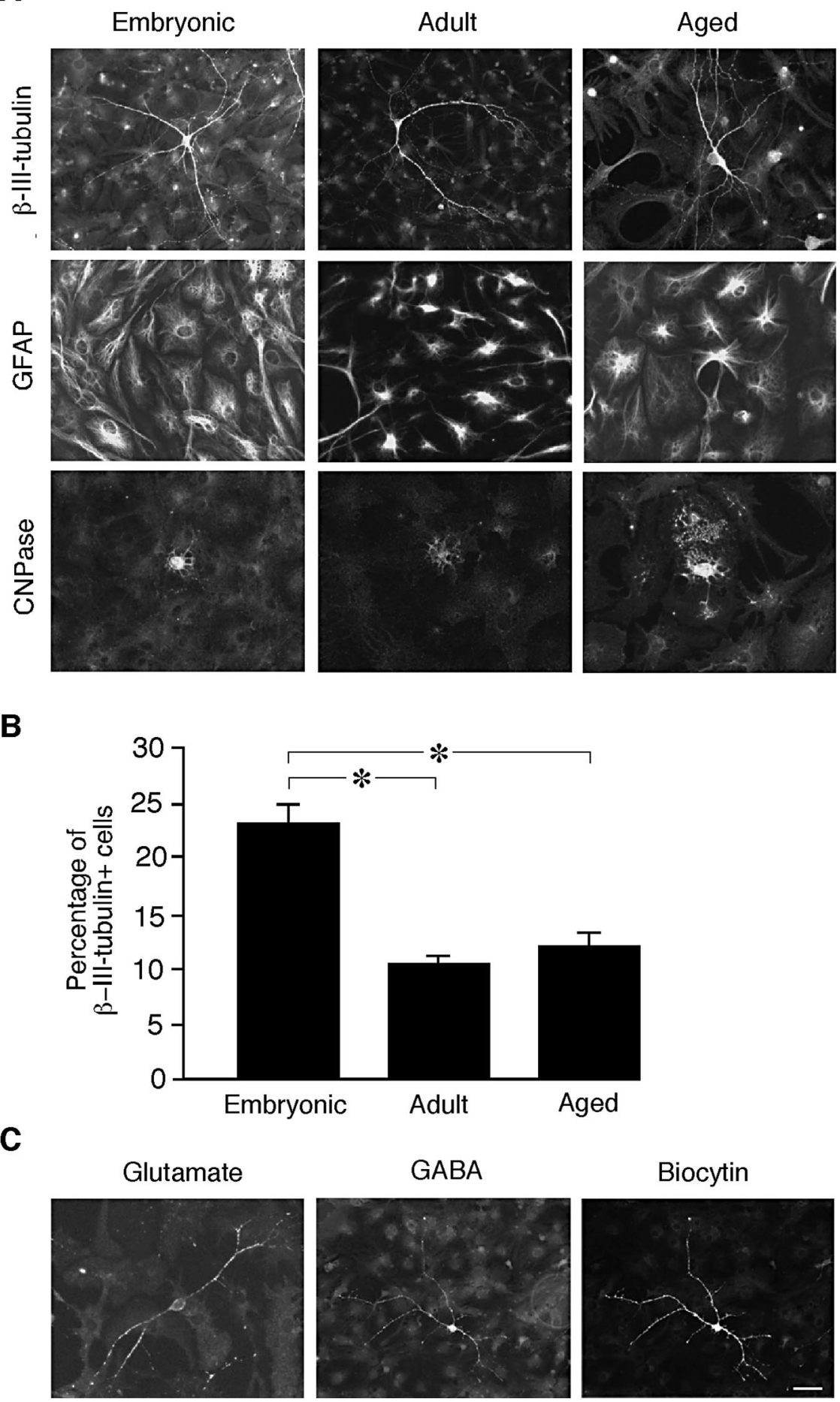

Figure 5. Multilineage differentiation of embryonic, adult, and aged NSCS. $A$, Photomicrographs of cells with morphological and immunocytochemical characteristics of neurons ( $\beta$-III-tubulin + ), astrocytes (GFAP + ), and oligodendrocytes (CNPase + ) generated after differentiation (7 DIV) of neurospheres derived from embryonic LGE and adult and aged SVZ. B, Percentage of $\beta$-III-tubulin + cells out of all cells formed from embryonic LGE and adult and aged SVZ. Mean \pm SEM; ${ }^{*} p<0.05$, one-way ANOVA with Fisher's post hoc test. Four independent cultures were used for quantification. C, Photomicrograph showing a glutamate + cell and a GABA + cell derived from aged NSCs. The GABA + cell was a functional neuron as assessed by patch-clamp recordings of the same cell (indicated by biocytin labeling). Scale bar, $20 \mu \mathrm{m}$.
To further characterize $\mathrm{K}^{+}$channels, we used two specific blockers, TEA and 4AP. Addition of TEA to proliferating NSCs of all age groups blocked $60 \%$ of total potassium current $\left(I_{\mathrm{K}(\mathrm{DR}+\mathrm{A})}\right)$. Of remaining $\mathrm{K}^{+}$current, $60 \%$ (25\% of total) was blocked by 
Table 1. Passive electrical properties of cells from embryonic, adult, and aged neural stem cell cultures under proliferation and differentiation conditions

\begin{tabular}{|c|c|c|c|c|c|c|}
\hline & \multicolumn{2}{|l|}{ Embryonic } & \multicolumn{2}{|l|}{ Adult } & \multicolumn{2}{|l|}{ Aged } \\
\hline & Proliferation & Differentiation & Proliferation & Differentiation & Proliferation & Differentiation \\
\hline Capacitance (pF) & $11.9 \pm 0.7(n=30)$ & $23.3 \pm 2.3(n=27)$ & $15.1 \pm 0.8(n=27)$ & $19.1 \pm 2.1(n=17)$ & $13 \pm 0.1(n=24)$ & $23.2 \pm 1.8(n=15)$ \\
\hline Input resistance (G $\Omega$ ) & $1.7 \pm 0.3(n=16)$ & $1.8 \pm 0.3(n=19)$ & $1.2 \pm 0.4(n=13)$ & $2 \pm 0.3(n=13)$ & $2.9 \pm 0.8(n=8)$ & $2 \pm 0.4(n=12)$ \\
\hline Resting membrane potential (mV) & $-59.7 \pm 2.8(n=20)$ & $-62.5 \pm 1.0(n=25)$ & $-65.1 \pm 4.5(n=15)$ & $-65.6 \pm 2.8(n=16)$ & $-56.8 \pm 5.4(n=14)$ & $-66.7 \pm 2.3(n=12)$ \\
\hline Action potential threshold (mV) & & $-31.3 \pm 1.2(n=23)$ & & $-29.3 \pm 1.5(n=16)$ & & $-29.4 \pm 1(n=11)$ \\
\hline Action potential amplitude (mV) & & $49.9 \pm 2.2(n=23)$ & & $45.2 \pm 3.9(n=16)$ & & $39.8 \pm 2.3(n=11)$ \\
\hline Action potential duration (ms) & & $4.5 \pm 0.3(n=23)$ & & $5.0 \pm 0.5(n=16)$ & & $3.9 \pm 0.4(n=11)$ \\
\hline Action potential after-hyperpolarization (mV) & & $14.6 \pm 1.2(n=23)$ & & $13.2 \pm 1.8(n=16)$ & & $14.3 \pm 2.1(n=11)$ \\
\hline
\end{tabular}

A
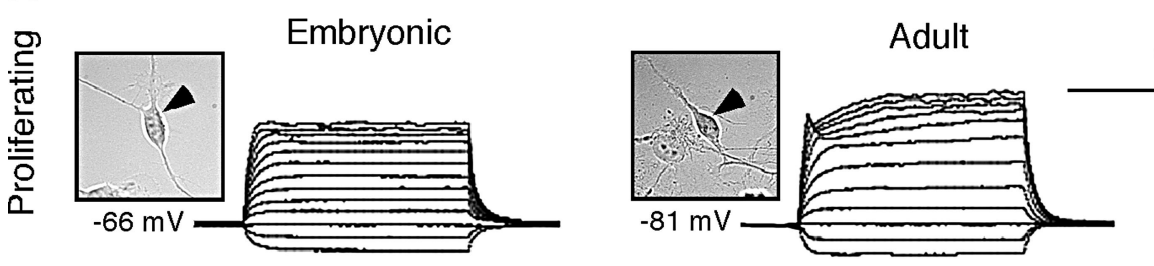

Aged
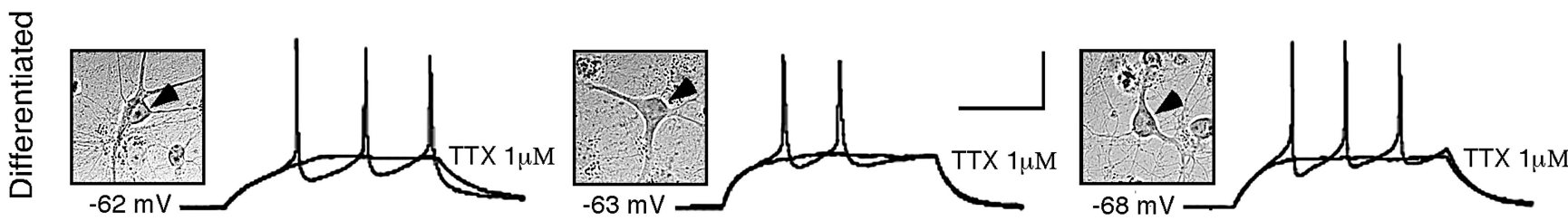

B

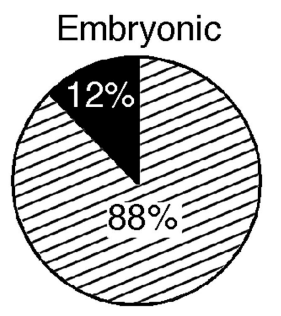

Immature AP

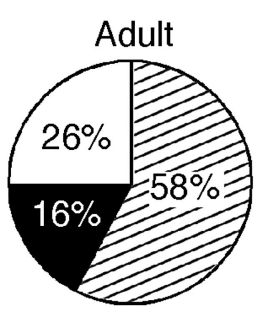

目 Mature AP

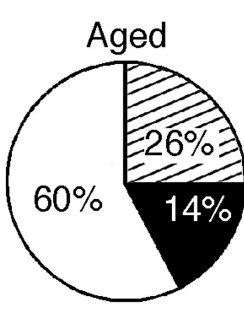

No AP

C

Figure 6. Active membrane properties of embryonic, adult, and aged NSCS. A, Responses to depolarizing or hyperpolarizing current injections in embryonic, adult, and aged proliferating (top) and differentiated (bottom) NSCs. Currents were injected for $500 \mathrm{~ms}$ in $20 \mathrm{pA}$ increments every $5 \mathrm{~s}$. Insets show microscopic images of corresponding cells with arrowheads depicting the recorded cells. Complete blockade of discharge responses to depolarizing current injections of $10 \mathrm{pA}$ in differentiated cells by $1 \mu \mathrm{m} \mathrm{TTX}$ is also shown. Calibration: $20 \mathrm{mV}, 200 \mathrm{~ms} . n=16,13,13$ (top), and 23, 22, and 11 (bottom) for embryonic, adult, and aged, respectively. $B$, Percentage of neurons responding to membrane depolarization with generation of immature, mature, or no AP embryonic ( $n=$ $26)$, adult $(n=38)$, and aged group $(n=42)$. C, Expression of $\mathrm{Na}^{+}$currents in neurons differentiated from embryonic, adult, and aged NSCs induced by voltage steps from -70 to $0 \mathrm{mV}$ in the absence and presence of $1 \mu \mathrm{m}$ TTX. Calibration: $200 \mathrm{pA}, 5 \mathrm{~ms} . n=6$ for embryonic, 7 for adult, and 7 for aged.

4AP. If AP was added first, $\sim 70 \%$ of the $\mathrm{K}^{+}$current was blocked. The rest constituted a very slow-inactivating current of which $50 \%$ ( $15 \%$ of total) was blocked by TEA. With both TEA and 4AP in bath solution, more than $80 \%$ of the total $\mathrm{K}^{+}$current was blocked in embryonic, adult, and aged NSCs (Fig. $8 A-C$ ). Together, our data indicate that more $\tan 50 \%$ of total potassium channels are sensitive to both TEA and 4AP, and a minor portion to either TEA or 4AP.

In contrast to proliferating cells, after addition of TEA to differentiated cells of all age groups, $\sim 60-70 \%$ of fast-inactivating $\mathrm{K}^{+}$current remained (Fig. 8D), of which 70\% (45\% of total) were blocked by $4 \mathrm{AP}$. Application of $4 \mathrm{AP}$ to the total current blocked $\sim 20 \%$ of the $\mathrm{K}^{+}$current. The remaining $80 \%$ constituted a very slow-inactivating current of which $75 \%$ (60\% of total $\mathrm{K}^{+}$current) was blocked by TEA. Using both TEA and 4AP, $\sim 80 \%$ of total $\mathrm{K}^{+}$current was blocked in neurons differentiated from embryonic, adult, and aged NSCs (Fig. $8 D$ ). These results indicate that during differentiation of NSCs from all ages, the composition of membrane $\mathrm{K}^{+}$channels changed, being blocked by either TEA or 4AP.

We finally investigated whether the neurons generated from NSCs obtained from various ages had functional glutamate and GABA receptors. Application of $100 \mu \mathrm{M}$ glutamate (Fig. $8 G$ ) or GABA (Fig. $8 H$ ) induced inward currents in neurons differentiated from NSCs of all ages. The glutamate-induced current was only partially blocked by $10 \mu \mathrm{M}$ NBQX and $50 \mu \mathrm{M}$ D-AP5.

\section{Discussion}

Here, we show age-dependent loss of NSCs and reduction in SVZ neurogenesis, accompanied by decreased gene expression of NSC markers, developmentally important transcription factors, and neurogenic factors. However, when the NSCs are expanded in vitro, they behave similarly, although with lower efficacy, as their counterparts from adult animals with respect to sphere-forming 
A

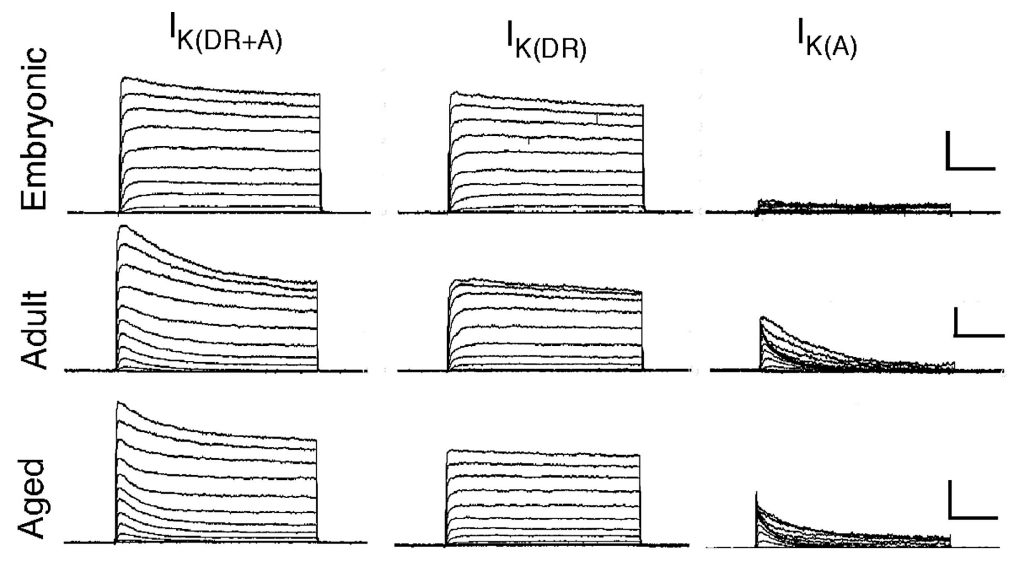

B

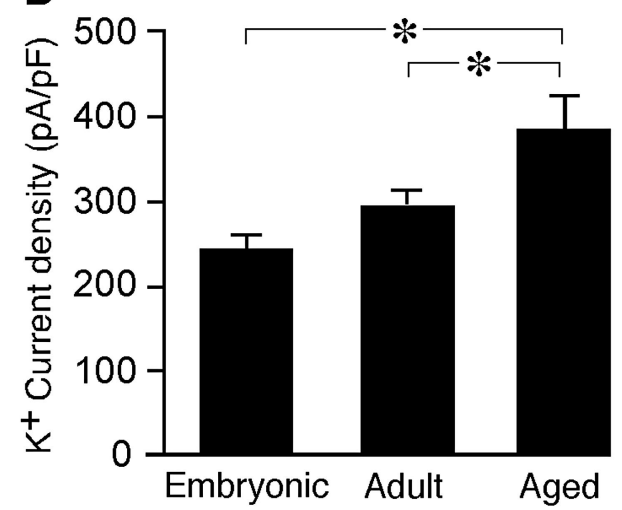

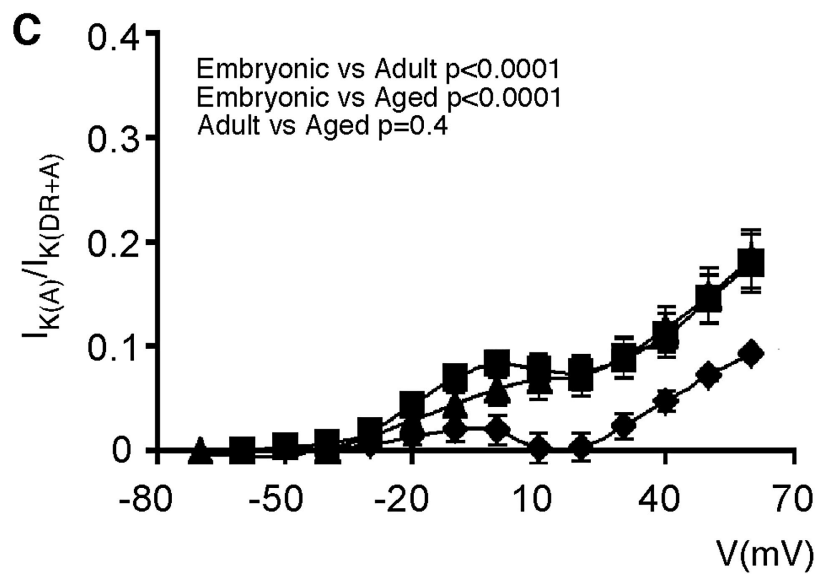

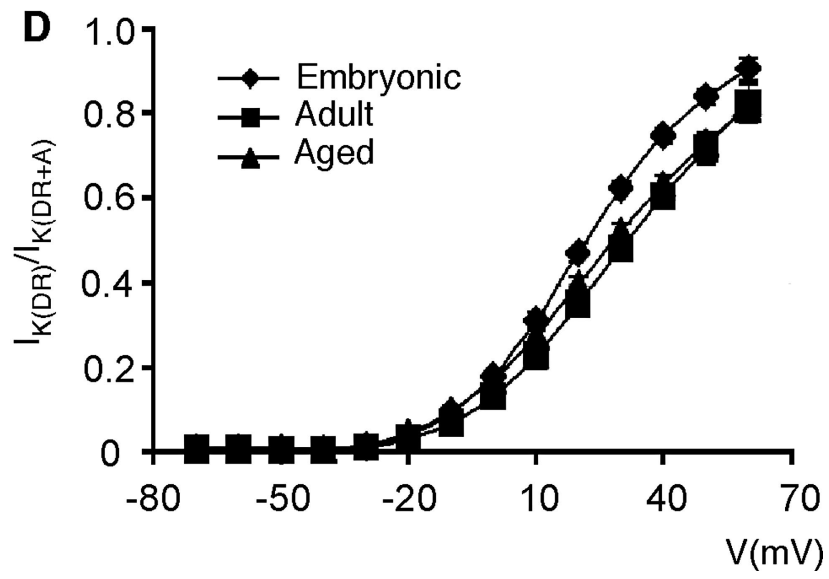

Figure 7. Expression of $\mathrm{K}^{+}$currents in proliferating cells. $A$, Total $\mathrm{K}^{+}$current $\left(I_{\mathrm{k}(\mathrm{DR}+\mathrm{A})} ;\right.$ left), non-inactivating delayed-rectified current $\left(I_{\mathrm{K}(\mathrm{DR})}\right.$; middle), and a fast-inactivating A-type $\mathrm{K}^{+}$current $\left(I_{K}\left(A_{A}\right)\right.$; right) obtained by voltage steps from -70 to $+60 \mathrm{mV}$ after a hyperpolarizing prepulse to $-110 \mathrm{mV}$ in proliferating embryonic, adult, and aged NS(S. $I_{K(D R)}$ was separated from total $I_{K}\left(C_{A}\right)$ using a depolarizing prepulse to $-40 \mathrm{mV}$. Calibration: $1 \mathrm{nA}, 50 \mathrm{~ms} . \boldsymbol{B}, \mathrm{K}^{+}$current density at $+60 \mathrm{mV}$. C, D, Mean \pm SEM. Mean proportion $I_{K}\left({ }_{A}\right)(\boldsymbol{C})$, and $I_{K(D R)}(\boldsymbol{D})$ out of total current plotted against the applied voltage steps for embryonic, adult, and aged NSCs, respectively. In C, comparison with repeated-measures ANOVA. $n=19,20,21$ in embryonic, adult, and aged, respectively.

capacity, proliferation, multilineage differentiation, and production of electrophysiologically functional neurons.

Reduction of SVZ cell proliferation has been reported previously by several groups (Tropepe et al., 1997; Enwere et al., 2004; Maslov et al., 2004; Luo et al., 2006). However, the changes in the number of cells expressing the cell cycle markers used in these studies could also reflect age-related alterations in the duration of different phases of the cell cycle as observed in adult SVZ cells after stroke (Zhang et al., 2006, 2008). We used both BrdU labeling and the mitotic marker, $\mathrm{p}-\mathrm{H} 3$, which is specifically expressed by cells undergoing mitotic division. Importantly, our finding of reduced number of $\mathrm{p}-\mathrm{H} 3+$ cells for the first time directly shows that the number of NSCs undergoing actual mitotic division at a given time is decreased severalfold in the aged SVZ. Furthermore, by using double staining with BrdU and phenotypic markers, we demonstrated that the mitotic activity of Sox $2+$ NSCs and Dcx + neuroblasts is decreased in the aged compared with the adult brain.

Although various mechanisms underlying the reduced neurogenesis in the aged brain have been suggested (Tropepe et al., 1997; Cameron and McKay, 1999; Montaron et al., 1999, 2006; Enwere et al., 2004; Shetty et al., 2005; Molofsky et al., 2006), it has been unclear whether the SVZ NSC pool diminishes with age. Together, our experimental evidence strongly indicates that aging leads to a loss of NSCs in the SVZ. First, we showed for the first time that the numbers of nestin-, Sox2-, and Gsh2- immunoreactive cells were decreased in the SVZ of aged animals. Second, we found overall reduction in gene expression of several NSC markers, i.e., nestin, Sox2, Gsh2, and Er81 in GFP+ cells sorted from the SVZ of nestin-GFP mice, indicating a loss of NSCs within the nestin-GFP+ population or reduced gene expression in the NSCs themselves. Third, we observed a decrease in primary neurosphere formation in aged animals, partially reflecting the number of NSCs in the SVZ, and neurosphere formation was rescued in these animals by enriching for NSCs from SVZ using cell sorting in nestin-GFP mice. These findings are at variance with two previous studies in which no change in number of NSCs was found in the aged rat hippocampus or mouse SVZ (Tropepe et al., 1997; Hattiangady and Shetty, 2008). However, our findings are supported by the work of Luo et al. (2006), who detected a loss of transient amplifying cells (so-called C-cells) in the aged mouse SVZ using electron microscopy.

The NSCs from embryonic LGE proliferated faster and gave rise to higher numbers of more mature and functional neurons than adult and aged cells. These findings identify embryonic LGE as the most suitable cell source for transplantation purposes. However, also NSCs from adult and aged mice proliferated extensively in vitro, despite the higher levels of SA- $\beta$-gal, increased gene expression of several factors involved in cell cycle arrest, and decreased proliferation with age, differentiated into cells of all lineages, including functional neurons. Thus, when taken out of their normal environment and challenged with growth factors, 

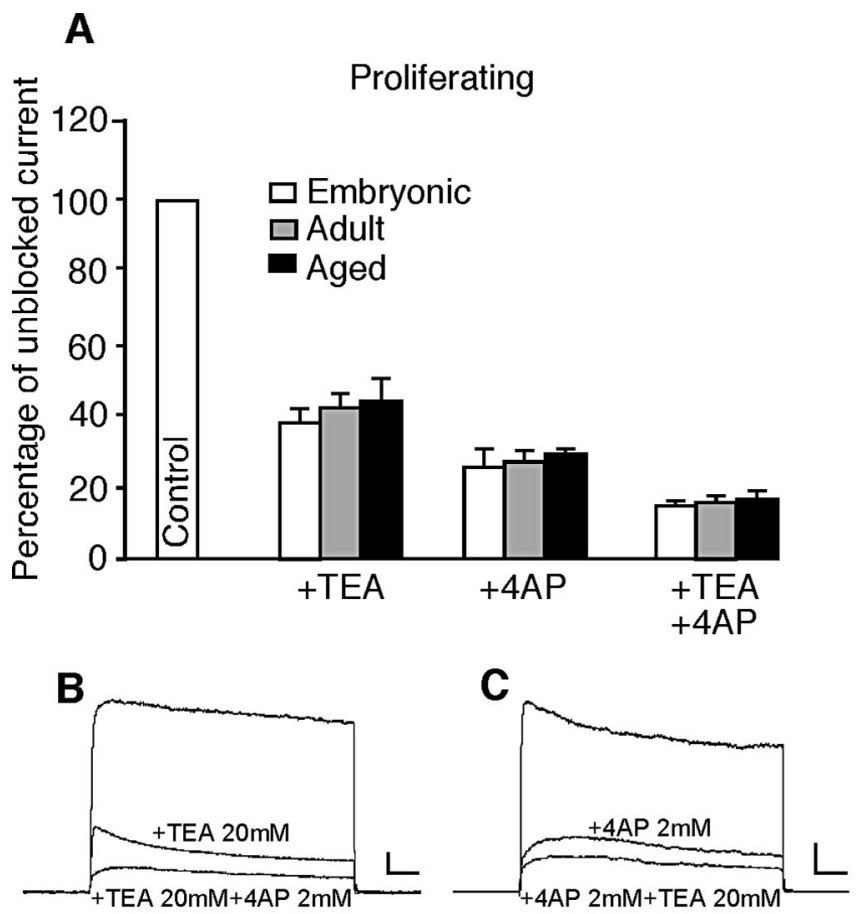

G
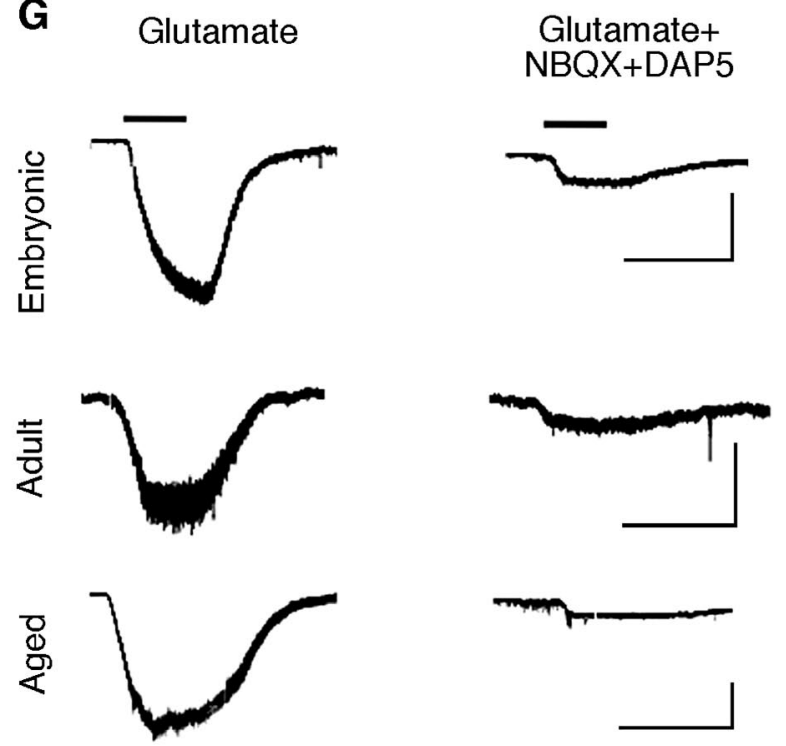
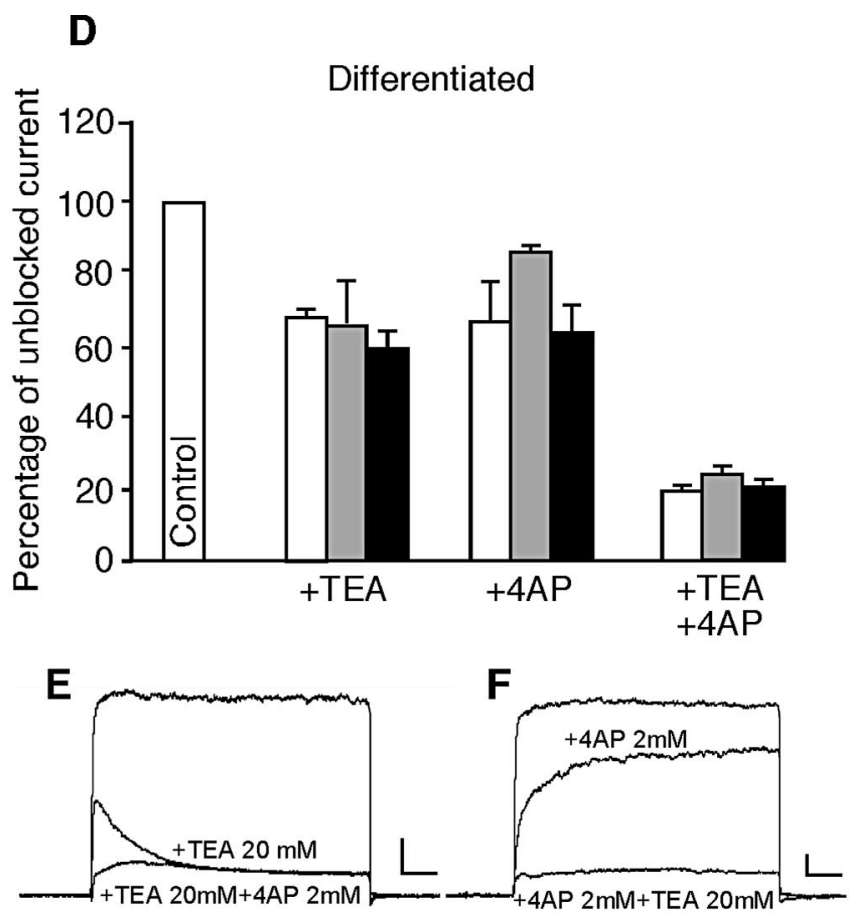

H
Glutamate+
NBQX+DAP5
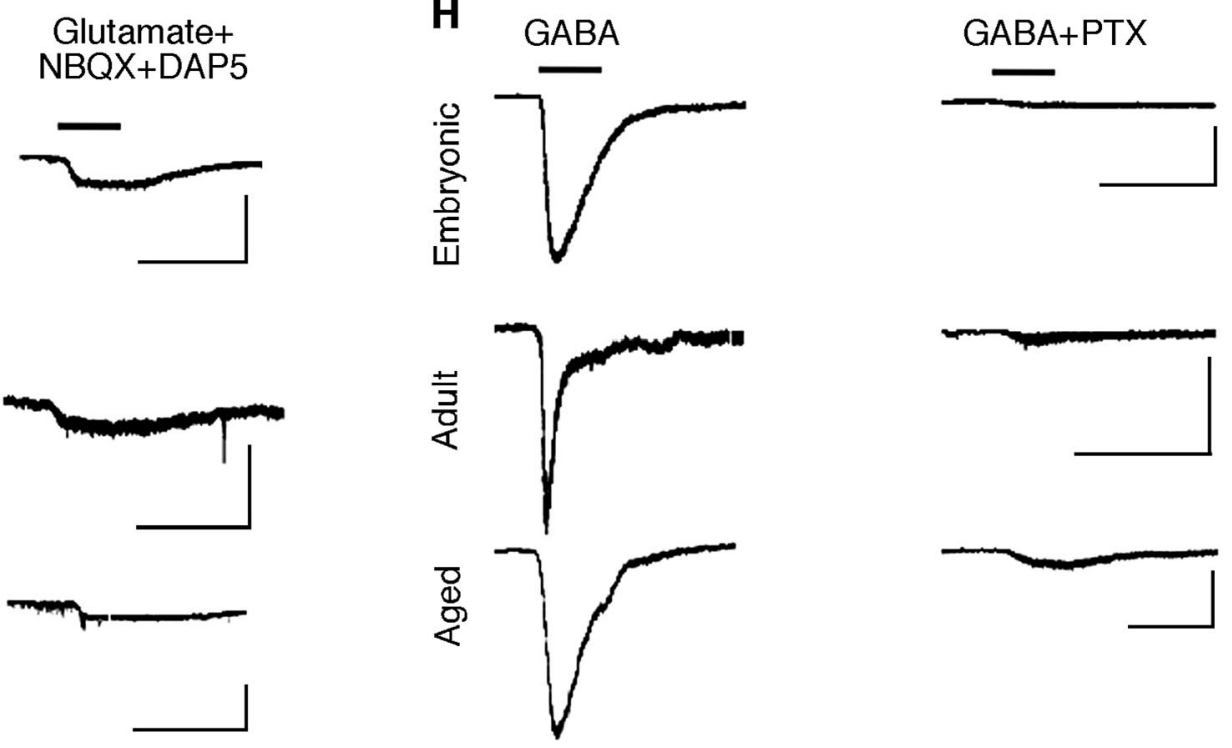

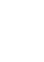

Figure 8. $\mathrm{K}^{+}$channel sensitivity to TEA and 4AP in embryonic, adult, and aged NSCs. A, Percentage of the current left unblocked by $20 \mathrm{~mm}$ TEA, 2 mm 4AP, or $20 \mathrm{~mm}$ TEA and 2 mM 4 AP in proliferating embryonic, adult, and aged NSCS. Means \pm SEM; $n=11,10,7$ and $9,9,7$ and $17,17,13$ in embryonic, adult, and aged, respectively. $B, C$, Representative traces of outward K ${ }^{+}$currents activated by a depolarizing voltage step from the resting membrane potential to $+40 \mathrm{mV}$ in proliferating NSCs. The currents are blocked by $20 \mathrm{~mm}$ TEA (B) or $2 \mathrm{~mm} 4 \mathrm{AP}$ (C). Calibration: $500 \mathrm{pA}, 25$ ms. $D$, Percentage of the current left unblocked by $20 \mathrm{~mm}$ TEA, $2 \mathrm{~mm} 4 \mathrm{AP}$, or $20 \mathrm{~mm}$ TEA and $2 \mathrm{~mm} 4 \mathrm{AP}$ in neurons differentiated from embryonic, adult, and aged NSCs. Means \pm SEM; $n=5,5,5$ and 6,5,7 and 8, 10, 11 in embryonic, adult, and aged, respectively. $E$, $F$, Representative traces of outward $\mathrm{K}^{+}$currents activated by a depolarizing voltage step from the resting membrane potential to $+40 \mathrm{mV}$ in neurons differentiated from aged NSC. The currents are blocked by $20 \mathrm{~mm}$ TEA (E) or $2 \mathrm{~mm} 4 A \mathrm{P}(\boldsymbol{F})$. Calibration: $250 \mathrm{pA}, 25 \mathrm{~ms}$. $\boldsymbol{G}$, Effect of $100 \mu \mathrm{m}$ glutamate (left) or glutamate together with $10 \mu \mathrm{M} \mathrm{NBQX}$ and $50 \mu \mathrm{M} \mathrm{D}$-AP5 (right) on neurons differentiated from embryonic, adult, and aged NSCs. Calibration: for embryonic and aged, $100 \mathrm{pA}, 50 \mathrm{~ms}$; for adult cells, $20 \mathrm{pA}, 50$ ms. $n=6,8$, and 6 in embryonic, adult, and aged, respectively. $\boldsymbol{H}$, The effect of $100 \mu \mathrm{m} \mathrm{GABA}$ (left) or $100 \mu \mathrm{m}$ GABA together with $10 \mu \mathrm{m}$ PTX (right) on neurons differentiated from embryonic, adult, and aged NSCs. Calibration: for embryonic and aged, $500 \mathrm{pA}, 50 \mathrm{~ms}$; for adult cells, $40 \mathrm{pA}$ and $50 \mathrm{~ms} . n=8,7$, and 5 in embryonic, adult, and aged, respectively.

NSCs from adult and aged SVZ respond similarly. These findings are consistent with in vivo data showing that NSCs in aged SVZ increased their proliferation and neuroblast formation in response to brain damage or infusion of growth factors (Jin et al., 2003, 2004; Darsalia et al., 2005).

Although our findings indicate that the environment in the aged brain impairs NSC survival, proliferation, and differentia- tion, we also obtained evidence suggesting that age-dependent, intrinsic changes in the NSCs themselves play a role. Thus, we detected reduced expression of NSC markers, developmentally important transcription factors, and neurogenic factors. Also, aged NSCs did not generate as many functional neurons as adult cells despite the same in vitro conditions. This could be partly explained by the increased mutational load described in aged 
neurospheres, which most likely affects normal function (Bailey et al., 2004).

Previous studies have shown similar dendritic spine density (Morgenstern et al., 2008) and input resistance (CouillardDespres et al., 2006) of newly formed neurons in adult and aged hippocampus. Before our study, no electrophysiological recordings or functional assays had been performed on neurons derived from NSCs of aged SVZ either in vivo or in vitro. Here, we report an extensive electrophysiological characterization of both proliferating NSCs and neurons differentiated from NSCs in SVZ of embryonic, adult, and aged mice. We find that the NSCs derived from embryonic LGE, and adult and aged SVZ, generate functional neurons with similar electrophysiological properties. Under proliferating conditions, the cells of all age groups have similar passive membrane properties, characterized by hyperpolarized resting membrane potential and high input resistance. We found slightly higher membrane capacitance in adult and aged NSCs and also in the cellular membrane, high density of voltageactivated potassium channels, mainly delayed rectified channels that increased with the age of the cells. Since we observed lower cell survival in adult and aged groups, the latter observation could indicate higher predisposition of older cells to undergo apoptosis. Enhancement of plasma membrane permeability to $\mathrm{K}^{+}$ions is known to be associated with apoptosis in various cell types (Bortner et al., 1997; Yu et al., 1997, 1999; Hribar et al., 2004). Delayed rectified $\mathrm{K}^{+}$current in proliferating embryonic NSCs cells and lack of A-type $\mathrm{K}^{+}$current have been reported (Pagani et al., 2006). However, in adult and aged NSCs, we also observed a fast-inactivating A-type $\mathrm{K}^{+}$current. Several studies have reported the occurrence of transient A-type $\mathrm{K}^{+}$current during neuronal differentiation (Barish, 1986; Wakazono et al., 1997). The channel population responsible for this A-type current has the activation curve shifted toward negative potentials, and it is probably composed of channels belonging to the Kv4 and/or Kv1.4 family (Coetzee et al., 1999). Together, the higher membrane capacitance, expression of fast-inactivating A-type $\mathrm{K}^{+}$ channels resembling the ones in differentiated neurons, and the presence of small densities of $\mathrm{Na}^{+}$channels in proliferating adult and aged NSCs indicate a more advanced stage of development of these cells compared with embryonic NSCs.

In all age groups, most of the $\mathrm{K}^{+}$channels in NSCs were sensitive to both TEA and 4AP, whereas a small percentage $(\sim 10-20 \%)$ were sensitive to either TEA or 4AP. From channel sensitivity to TEA and 4AP, as well as the positive shift of the activation curves, we can conclude that at the proliferative stage, most of the current flows through $\mathrm{K}^{+}$channels of the Kv3 family (Grissmer et al., 1994; Coetzee et al., 1999).

Ion channel composition also changed during differentiation (Hribar et al., 2004). We observed a decrease of $\mathrm{K}^{+}$channel density in comparison with the proliferating stage but with no differences between age groups. The main $\mathrm{K}^{+}$channel population was still delayed rectified channels, but a fast-inactivating A-type current developed in neurons generated from embryonic NSCs similar to the one present in proliferating adult and aged NSCs. In the adult and aged groups, the A-type current did not change during differentiation. We could not encounter any differences regarding the expression of $\mathrm{K}^{+}$channel populations between the age groups. Although $\mathrm{K}^{+}$channel activation kinetics were similar to the ones observed in the proliferating stage, TEA and 4AP sensitivity changed during differentiation. Thus, the channels were less sensitive to TEA and even to a lesser extent to $4 \mathrm{AP}$, indicating that the $\mathrm{K}^{+}$channel population of differentiated neurons is constituted from both Kv2 and Kv3 families (Grissmer et al., 1994; Coetzee et al., 1999). However, TEA and 4AP sensitivity was similar in neurons differentiated from cells of the three age groups. One characteristic feature of the differentiated neurons was the presence of a high density of $\mathrm{Na}^{+}$channels. Mature neurons with complex morphologies were generated from NSCs of all age groups. After 2 weeks of differentiation, these neurons were firing repetitive APs that could be abolished by TTX and were able to respond to applications of glutamate or GABA. Importantly, despite the decrease in the number of differentiated neurons with age, we could not detect any changes in the functional electrophysiological properties of the individual neurons. Thus, our findings indicate that neurons differentiated from NSCs of embryonic LGE and adult and aged SVZ have similar potential for functional integration.

Together, our findings show that aging is associated with a loss of NSCs in the SVZ but that the remaining cells retain their ability for proliferation and differentiation if removed from the aged environment. Moreover, aged NSCs generate functional neurons, which are indistinguishable by their passive and active electrophysiological properties. This knowledge is potentially useful as basis for future attempts to use endogenous neurogenesis for brain repair in elderly patients with acute or chronic neurodegenerative disease.

\section{References}

Bailey KJ, Maslov AY, Pruitt SC (2004) Accumulation of mutations and somatic selection in aging neural stem/progenitor cells. Aging Cell 3:391-397.

Barish ME (1986) Differentiation of voltage-gated potassium current and modulation of excitability in cultured amphibian spinal neurones. J Physiol 375:229-250.

Bortner CD, Hughes FM Jr, Cidlowski JA (1997) A primary role for K+ and $\mathrm{Na}+$ efflux in the activation of apoptosis. J Biol Chem 272:32436-32442.

Brown JP, Couillard-Després S, Cooper-Kuhn CM, Winkler J, Aigner L, Kuhn HG (2003) Transient expression of doublecortin during adult neurogenesis. J Comp Neurol 467:1-10.

Cameron HA, McKay RD (1999) Restoring production of hippocampal neurons in old age. Nat Neurosci 2:894-897.

Coetzee WA, Amarillo Y, Chiu J, Chow A, Lau D, McCormack T, Moreno H, Nadal MS, Ozaita A, Pountney D, Saganich M, Vega-Saenz de Miera E, Rudy B (1999) Molecular diversity of K+ channels. Ann N Y Acad Sci 868:233-285.

Couillard-Despres S, Winner B, Karl C, Lindemann G, Schmid P, Aigner R, Laemke J, Bogdahn U, Winkler J, Bischofberger J, Aigner L (2006) Targeted transgene expression in neuronal precursors: watching young neurons in the old brain. Eur J Neurosci 6:1535-1545.

Darsalia V, Heldmann U, Lindvall O, Kokaia Z (2005) Stroke-induced neurogenesis in aged brain. Stroke 36:1790-1795.

Doetsch F, Petreanu L, Caille I, Garcia-Verdugo JM, Alvarez-Buylla A (2002) EGF converts transit-amplifying neurogenic precursors in the adult brain into multipotent stem cells. Neuron 36:1021-1034.

Ellis P, Fagan BM, Magness ST, Hutton S, Taranova O, Hayashi S, McMahon A, Rao M, Pevny L (2004) SOX2, a persistent marker for multipotential neural stem cells derived from embryonic stem cells, the embryo or the adult. Dev Neurosci 26:148-165.

Enwere E, Shingo T, Gregg C, Fujikawa H, Ohta S, Weiss S (2004) Aging results in reduced epidermal growth factor receptor signaling, diminished olfactory neurogenesis, and deficits in fine olfactory discrimination. J Neurosci 24:8354-8365.

Gray WP, May K, Sundström LE (2002) Seizure induced dentate neurogenesis does not diminish with age in rats. Neurosci Lett 330:235-238.

Grissmer S, Nguyen AN, Aiyar J, Hanson DC, Mather RJ, Gutman GA, Karmilowicz MJ, Auperin DD, Chandy KG (1994) Pharmacological characterization of five cloned voltage-gated $\mathrm{K}+$ channels, types Kv1.1, $1.2,1.3,1.5$, and 3.1 , stably expressed in mammalian cell lines. Mol Pharmacol 45:1227-1234.

Gundersen HJ, Jensen EB (1987) The efficiency of systematic sampling in stereology and its prediction. J Microsc 147:229-263.

Hamill OP, Marty A, Neher E, Sakmann B, Sigworth FJ (1981) Improved 
patch-clamp techniques for high-resolution current recording from cells and cell-free membrane patches. Pflugers Arch 391:85-100.

Hattiangady B, Shetty AK (2008) Aging does not alter the number or phenotype of putative stem/progenitor cells in the neurogenic region of the hippocampus. Neurobiol Aging 29:129-147.

Hribar M, Bloc A, Medilanski J, Nüsch L, Eder-Colli L (2004) Voltage-gated $\mathrm{K}+$ current: a marker for apoptosis in differentiating neuronal progenitor cells? Eur J Neurosci 20:635-648.

Jin K, Sun Y, Xie L, Batteur S, Mao XO, Smelick C, Logvinova A, Greenberg DA (2003) Neurogenesis and aging: FGF-2 and HB-EGF restore neurogenesis in hippocampus and subventricular zone of aged mice. Aging Cell 2:175-183.

Jin K, Minami M, Xie L, Sun Y, Mao XO, Wang Y, Simon RP, Greenberg DA (2004) Ischemia-induced neurogenesis is preserved but reduced in the aged rodent brain. Aging Cell 3:373-377.

Kempermann G, Gast D, Gage FH (2002) Neuroplasticity in old age: sustained fivefold induction of hippocampal neurogenesis by long-term environmental enrichment. Ann Neurol 52:135-143.

Lendahl U, Zimmerman LB, McKay RD (1990) CNS stem cells express a new class of intermediate filament protein. Cell 60:585-595.

Lindvall O, Kokaia Z (2008) Neurogenesis following stroke affecting the adult brain. In: Adult neurogenesis. New York: Cold Spring Harbor Laboratory.

Luo J, Daniels SB, Lennington JB, Notti RQ, Conover JC (2006) The aging neurogenic subventricular zone. Aging Cell 5:139-152.

Maslov AY, Barone TA, Plunkett RJ, Pruitt SC (2004) Neural stem cell detection, characterization, and age-related changes in the subventricular zone of mice. J Neurosci 24:1726-1733.

Molofsky AV, Slutsky SG, Joseph NM, He S, Pardal R, Krishnamurthy J, Sharpless NE, Morrison SJ (2006) Increasing p16INK4a expression decreases forebrain progenitors and neurogenesis during ageing. Nature 443:448-452.

Montaron MF, Petry KG, Rodriguez JJ, Marinelli M, Aurousseau C, Rougon G, Le Moal M, Abrous DN (1999) Adrenalectomy increases neurogenesis but not PSA-NCAM expression in aged dentate gyrus. Eur J Neurosci 11:1479-1485.

Montaron MF, Drapeau E, Dupret D, Kitchener P, Aurousseau C, Le Moal M, Piazza PV, Abrous DN (2006) Lifelong corticosterone level determines age-related decline in neurogenesis and memory. Neurobiol Aging 27:645-654.

Morgenstern NA, Lombardi G, Schinder AF (2008) Newborn granule cells in the ageing dentate gyrus. J Physiol 586:3751-3757.

Olariu A, Cleaver KM, Cameron HA (2007) Decreased neurogenesis in aged rats results from loss of granule cell precursors without lengthening of the cell cycle. J Comp Neurol 501:659-667.

Pagani F, Lauro C, Fucile S, Catalano M, Limatola C, Eusebi F, Grassi F (2006) Functional properties of neurons derived from fetal mouse neu- rospheres are compatible with those of neuronal precursors in vivo. J Neurosci Res 83:1494-1501.

Parmar M, Sjöberg A, Björklund A, Kokaia Z (2003) Phenotypic and molecular identity of cells in the adult subventricular zone. in vivo and after expansion in vitro. Mol Cell Neurosci 24:741-752.

Paxinos G, Watson C (1997) The rat brain in stereotaxic coordinates, Ed 3. San Diego: Academic.

Rao MS, Hattiangady B, Shetty AK (2008) Status epilepticus during old age is not associated with enhanced hippocampal neurogenesis. Hippocampus 18:931-944.

Sakakibara S, Okano H (1997) Expression of neural RNA-binding proteins in the postnatal CNS: implications of their roles in neuronal and glial cell development. J Neurosci 17:8300-8312.

Sakakibara S, Imai T, Hamaguchi K, Okabe M, Aruga J, Nakajima K, Yasutomi D, Nagata T, Kurihara Y, Uesugi S, Miyata T, Ogawa M, Mikoshiba K, Okano H (1996) Mouse-Musashi-1, a neural RNA-binding protein highly enriched in the mammalian CNS stem cell. Dev Biol 176:230-242.

Shetty AK, Hattiangady B, Shetty GA (2005) Stem/progenitor cell proliferation factors FGF-2, IGF-1, and VEGF exhibit early decline during the course of aging in the hippocampus: role of astrocytes. Glia 51:173-186.

Stenman J, Toresson H, Campbell K (2003) Identification of two distinct progenitor populations in the lateral ganglionic eminence: implications for striatal and olfactory bulb neurogenesis. J Neurosci 23:167-174.

Tropepe V, Craig CG, Morshead CM, van der Kooy D (1997) Transforming growth factor-alpha null and senescent mice show decreased neural progenitor cell proliferation in the forebrain subependyma. J Neurosci 17:7850-7859.

Wakazono Y, Kurahashi T, Nakahira K, Nagata I, Takayama C, Inoue Y, Kaneko A, Ikenaka K (1997) Appearance of a fast inactivating voltagedependent $\mathrm{K}+$ currents in developing cerebellar granule cells in vitro. Neurosci Res 29:291-301.

Yu SP, Yeh CH, Sensi SL, Gwag BJ, Canzoniero LM, Farhangrazi ZS, Ying HS, Tian M, Dugan LL, Choi DW (1997) Mediation of neuronal apoptosis by enhancement of outward potassium current. Science 278:114-117.

Yu SP, Yeh CH, Gottron F, Wang X, Grabb MC, Choi DW (1999) Role of the outward delayed rectifier $\mathrm{K}+$ current in ceramide-induced caspase activation and apoptosis in cultured cortical neurons. J Neurochem 73:933-941.

Zhang RL, Zhang ZG, Lu M, Wang Y, Yang JJ, Chopp M (2006) Reduction of the cell cycle length by decreasing G1 phase and cell cycle reentry expand neuronal progenitor cells in the subventricular zone of adult rat after stroke. J Cereb Blood Flow Metab 26:857-863.

Zhang RL, Zhang ZG, Roberts C, LeTourneau Y, Lu M, Zhang L, Wang Y, Chopp M (2008) Lengthening the G(1) phase of neural progenitor cells is concurrent with an increase of symmetric neuron generating division after stroke. J Cereb Blood Flow Metab 28:602-611. 